\title{
Storm-generated Holocene and historical floods in the Manawatu River, New Zealand
}

\author{
Ian C. FULLER ${ }^{1 *}$, Mark G. MACKLIN ${ }^{1,2}$, Willem H.J. TOONEN ${ }^{3}$, Katherine A. HOLT ${ }^{1}$ \\ ${ }^{1}$ Innovative River Solutions \& Physical Geography Group, School of Agriculture \& Environment, Massey \\ University, Palmerston North, New Zealand \\ ${ }^{2}$ School of Geography \& Lincoln Centre for Water and Planetary Health, University of Lincoln, Lincoln, UK \\ ${ }^{3}$ Department of Geography \& Earth Science, Aberystwyth University, Aberystwyth, UK \\ *Corresponding author: Tel.: +64 6356 9099; Fax: +64 350 5680; E-mail: I.C.Fuller@massey.ac.nz
}

\section{Abstract}

This paper reports the first reconstruction of storm-generated late Holocene and historical river floods in the North Island of New Zealand. The sedimentary infills of nine palaeochannels were studied in the lower alluvial reaches of the Manawatu River. Floods in these palaeochannels were recorded as a series of sand-rich units set within finer-grained fills. Flood chronologies were constrained using a combination of radiocarbon dating, documentary sources, geochemical markers, and palynological information. Flood units were sedimentologically and geochemically characterised using high resolution ITRAX ${ }^{\mathrm{TM}} \mathrm{X}$-Ray Fluorescence (XRF) core scanning and laser diffraction grain-size analysis. The longest palaeoflood record extends back ca.3000 years. The temporal resolution and length of the Manawatu record reflects accommodation space for fluvial deposits, channel dynamics and mobility, and high sediment supply. Floods that occurred in the Manawatu during the mid-1800s at the time of European land clearance and in the first decade of the twentieth century appear to be among the largest recorded in the last 3000 years.

Keywords: fluvial sedimentary archive, palaeochannel, floodplain, XRF analysis

\section{Introduction}

Palaeoflood research in New Zealand to date has largely focused on volcanogenic break-out floods associated with the ca. A.D. 180 Taupo eruption (Manville et al., 1999, 2005), 26.5 ka Oruanui eruption from the same caldera (Manville and Wilson, 2004), and lahars generated within the Taupo Volcanic Zone (Manville, 2004; Graettinger et al., 2010; Manville and Hodgson, 2011). Little attention has been given to palaeofloods beyond New Zealand's volcanic terrain, and yet storm-generated flooding is the most frequent natural hazard in New Zealand, with over 1000 serious events in the last 100 years (Willis, 2014). Assessing flood risk is, however, presently constrained by short (generally less than 60 year) gauged river flow records that poorly represent the distribution of hydrological extremes (Fuller et al., 2016). The peak discharges of early twentieth century floods have been estimated on the basis of historical records (e.g., Cowie, 1957), but human recording of floods in New Zealand is limited by its very recent colonisation, and there is a paucity of documentary evidence. Recent work using metaanalysis of a radiocarbon database developed from New Zealand Holocene alluvial records (Macklin et al., 2012; Richardson et al., 2013; Fuller et al., 2015) has produced centennial-scale records of flooding in New Zealand as a whole. While this approach has been able to identify flood-rich and flood- 
poor episodes throughout the Holocene, and relate these events to broad-scale synoptic forcing (Richardson et al., 2013), it does not enable event-scale, storm-generated palaeoflood reconstruction.

Recent studies of lowland alluvial river systems have demonstrated that the grain size of individual flood beds, contained in the infill of abandoned meanders, can be used to reconstruct (palaeo)flood series (Munoz et al., 2015; Toonen et al., 2015). These records provide a tool to place recorded extreme events in a framework of long-term flooding variability. Moreover, longer flood series allow detection of distinctive phases and episodes of flooding in addition to individual events (Toonen et al., 2017), which allows comparison with other regional hydroclimatic and biological records (e.g. Norton et al., 1989; Richardson et al., 2013; Fuller et al., 2015). Furthermore, a longer flood series makes it possible to identify underlying forcing, such as El Niño Southern Oscillation (ENSO) for the Pacific region (Ely 1997; Kiem et al., 2003) including New Zealand, where the Antarctic Southern Annular Mode (SAM) is also important (Macklin et al., 2012; Richardson et al., 2013); and NAO/AMO (North Atlantic Oscillation / Atlantic Multidecadal Oscillation) for the Atlantic (Foulds and Macklin 2016; Toonen et al., 2016).

In this we paper we explore the gap in palaeoflood research in New Zealand by providing the first reconstruction of discrete storm-generated floods using analysis of the fluvial sedimentary archive, extending over the past $\sim 3000$ years. The catchment in which this work is situated lies beyond the volcanic terrain of the central North Island, removing the possibility of volcanogenic floods. The nature of topography in the Manawatu means that landslide dams in trunk rivers are rare, although significant elsewhere in New Zealand alpine terrain in association with coseismic events and/or rainfall (e.g. Korup 2002; Hancox 2005). The flood record presented here is, we believe, truly storm-generated.

\section{Site description}

\subsection{Manawatu catchment}

The Manawatu River drains a $5885 \mathrm{~km}^{2}$ catchment situated in southern North Island of New Zealand (Fig. 1). The catchment straddles the greywacke North Island axial ranges (Tararua and Ruahine) and comprises six primary tributaries, four of which rise on the east of these ranges (Fig. 1B). The study reach, adjacent to Palmerston North, is situated in the lower part of the catchment. Mean annual discharge for the Manawatu River is ca. $110 \mathrm{~m}^{3} \mathrm{~s}^{-1}$ with the most significant contributions derived from the upper Manawatu (ca. $27 \mathrm{~m}^{3} \mathrm{~s}^{-1}$ ), Mangatainoka (ca. $18 \mathrm{~m}^{3} \mathrm{~s}^{-1}$ ), Pohangina (ca. $17 \mathrm{~m}^{3} \mathrm{~s}^{-1}$ ), Tiraumea (ca. $16 \mathrm{~m}^{3} \mathrm{~s}^{-1}$ ), Mangahao (ca. $15 \mathrm{~m}^{3} \mathrm{~s}^{-1}$ ), and Oroua (ca. $13 \mathrm{~m}^{3} \mathrm{~s}^{-1}$ ) (figures derived from Henderson and Diettrich 2007). The catchment was extensively cleared of native forest in a period spanning the late 1800s and early 1900s to make way for mostly pastoral agriculture (Fig. 1C). Native forest remains on 
the greywacke ranges, which rise to $1695 \mathrm{~m}$ and $1505 \mathrm{~m}$ in the northernmost and southernmost parts of the catchment respectively. The Manawatu River crosses the axial range through the Manawatu Gorge, which is the only locality for significant dambreak floods in the trunk river and primary tributaries. However, the evidence is not clear (geological, documentary, or Maori oral tradition) of the river having been completely dammed by landslides here in the late Holocene, although the presence of large boulders in the channel floor of the Gorge indicates significant local, off-slope delivery. With the exception of the uplifted greywacke fault block, most of the catchment is underlain by soft sedimentary rock, notably mudstones and sandstones (Fig. 1D). Erosion of this terrain generates a suspended sediment yield from the Manawatu to the ocean of ca. $3.74 \mathrm{Mt} \mathrm{y}^{-1}$ (Hicks et al., 2011). While this volume of sediment discharge has no doubt been enhanced by land clearance (Hicks et al., 2011), the underlying soft-rock terrain is likely a naturally high sediment generator. Clement et al. (2017) recorded a rapid infilling of the Manawatu estuary within ca. 2700 years of the mid-Holocene sea level high-stand (7240-6500 cal. YBP). Tectonic uplift in the catchment is ca. 1-4 mm $\mathrm{y}^{-1}$ in the greywacke ranges (Wellman, 1972; Pillans, 1986; Whitehouse and Pearce, 1992), and river terraces generated by downcutting in response to this uplift are prominent landscape features in the upper and middle reaches of the primary valleys.

\section{Figure 1.}

\subsection{Climate}

Climate in the region is humid temperate; mean annual rainfall in Palmerston North is $\sim 980 \mathrm{~mm}$, rising to $>2000 \mathrm{~mm}$ in the Tararua and Ruahine ranges (NIWA 2017). Most rain in the catchment is brought by mid-latitude frontal systems approaching from the west, although subtropical depressions in late summer-autumn and southerly polar outbreaks (throughout the year) can bring easterly-quarter rain. Temperatures are mild: the mean temperature in the coldest month (July) is $8^{\circ} \mathrm{C}$, rising to $18^{\circ} \mathrm{C}$ in the warmest month (February). Snow at sea level is extremely rare ( 30 -year recurrence interval), although snowpacks above the tree line $(\sim 1000 \mathrm{~m})$ can develop during sustained cold periods.

\subsection{Floodplain topography}

In the lower Manawatu valley in the vicinity of Palmerston North, the valley floor widens and becomes unconfined as the river emerges into the Taonui basin (cf. Fig. 2). Here, a sequence of palaeochannels, abandoned by natural neck and chute cutoffs, has been well preserved on the floodplain (Fig. 2). 
Upstream of Palmerston North, the floodplain is bound by early Holocene and late Pleistocene river terraces, while a last interglacial marine terrace forms a higher $(100 \mathrm{~m})$ surface to the south of the floodplain (cf. Fig. 2 and Clement et al. 2010). River management has straightened the channel through much of this reach (Page and Heerdegen 1985), and the river is now largely disconnected from its floodplain by the Lower Manawatu Flood Protection Scheme, providing flood protection for the city of Palmerston North and for the high value dairy agriculture of the lower valley. The river gradient flattens significantly within this reach from 0.0012 upstream of the city to 0.0002 downstream of the 10-m contour (Fig. 2) (Page and Heerdegen 1985). The sequence of palaeochannels in the lower Manawatu was first described by Page and Heerdegen (1985), noting that they were already defunct at the time of a previous survey in 1859. Page and Heerdegen (1985) describe partial infilling of these palaeochannels with up to $8 \mathrm{~m}$ of fine-grained sediments overlaying gravels of the original channel bed, and their interpretation suggested that some of these channels were abandoned around 200 years prior to the 1859 survey because the depth of soil formation and amount of infilling, which was only a little greater than that of other dated cutoffs (1888 and 1937). If that interpretation was correct, these palaeochannels would yield records of past floods spanning 350 years. However, we should also note that Page and Heerdegen's mapping of the palaeochannel sequence is somewhat incomplete. Terrain surfaces generated from airborne LiDAR acquired by the Horizons Regional Council in 2006 have revealed several more distal and evidently older palaeochannels in the Manawatu. The full suite of palaeochannels is described by LoRe et al. (2018).

\section{Figure 2.}

\section{Methods and Data}

Cores of selected palaeochannels were recovered using a hydraulic percussion coring system in distal palaeochannels containing consolidated sequences and a Livingston piston corer in wetter palaeochannels with a soft sediment fill proximal to the current river. Cores were split, with one-half being shipped for ITRAX ${ }^{\mathrm{TM}}$ X-Ray Fluorescence (XRF) core scanning and grain-size analysis at Aberystwyth University (UK), while the remainder was sampled for palynological analysis and radiocarbon dating.

\subsection{Grain-size analysis and identification of flood units}


Flood units are identifiable as sandy layers in the silt-dominated cores (see Figs 6 and 7). A Malvern 2000 laser diffraction device was used to measure grain-size distribution of 1-cm-thick samples, taken at 5-10 cm intervals. Samples were pretreated with $\mathrm{Na}_{4} \mathrm{P}_{2} \mathrm{O}_{7} \cdot 10 \mathrm{H}_{2} \mathrm{O}$ and sonic disaggregation to disperse grains in order to prevent flocculation. In total, 402 samples were collected from the cores. Previous studies indicate that grain-size information of flood deposits can relate to flood magnitudes (Jones et al., 2012; Munoz et al., 2015; Toonen et al., 2015; Leigh, 2017). However, continuous study of flood laminae at a high-resolution ( $\mathrm{mm}$ scale) is inefficient and costly. Jones et al. (2012) demonstrated that the $\mathrm{Zr} / \mathrm{Rb}$ ratio provides a robust geochemical proxy for the grain size of flood deposits in low-gradient Welsh river systems. The element $\mathrm{Zr}$ is found principally in the resistant mineral zircon, while $\mathrm{Rb}$ is found in a range of minerals including clay minerals. Zirconium tends to become concentrated in fine sand to coarse silt, while $\mathrm{Rb}$ concentrates in fine silt and clay during sediment transport, which means an increasing $\mathrm{Zr} / \mathrm{Rb}$ ratio can be associated with an increase in grain size (Jones et al., 2012). The ITRAX'M XRF core scanning was used to measure core geochemistry at a 1-mm resolution.

To test the relation between direct measurement of grain size using laser diffraction and the $\mathrm{Zr} / \mathrm{Rb}$ geochemical proxy grain size, sampling targeted (i) visually recognisable coarse-grained flood layers and fine-grained background sedimentation (originating from more common events) and (ii) specific intervals of high or low (peak and troughs) $\mathrm{Zr} / \mathrm{Rb}$ ratios. This approach ensures that the $\mathrm{Zr} / \mathrm{Rb}$ grainsize proxy is validated for the full range of sediments that occurs in the channel fill sequences.

The $\mathrm{Zr} / \mathrm{Rb}$ count ratio was normalised for each single measurement using the sum of coherent and incoherent scatter (dependent upon organic and water content). Measurements were averaged over an 11-mm interval to fit with the sample size used for laser diffraction grain-size analysis. A comparison was made with the $D_{50}$ and $D_{90}$ parameters (Fig. 3A). The data are presented as a bulk ensemble for all sites because all sites are located in the same river reach and share a common stratigraphy, lithology, and catchment. The relation between $D_{50}$ and $D_{90}$ appears consistent between all sites and is significant ( $n=400, r=0.89, p<0.001$ ), cf. Fig. 3. A statistically significant relationship exists between the grain size and the $\mathrm{Zr} / \mathrm{Rb}$ ratio: $D_{50} \mathrm{Vs}$. $\mathrm{Zr} / \mathrm{Rb}(r=0.68, p<0.001$; Fig. $3 \mathrm{~B})$ and $D_{90} \mathrm{Vs}$. $\mathrm{Zr} / \mathrm{Rb}(r=0.49$, $p<0.001$ ). Both correlations are significant at $n=360$ (excluding the grain-size samples that do not overlap with geochemistry measurements e.g. near gaps and sections unsuitable for scanning). However, the $\mathrm{Zr} / \mathrm{Rb}$ ratio is more strongly correlated with the $D_{50}$ than the $D_{90}$. A divergence in the relationship between grain size and $\mathrm{Zr} / \mathrm{Rb}$ ratio occurs above $\sim 0.8$, and this corresponds to the greater proportion of medium sand deposited before the cutoffs were finally separated from the main flow 
represent flood magnitude variability as well as of $D_{90}$ at these sites. This test thus confirms that peaks in the $\mathrm{Zr} / \mathrm{Rb}$ ratio correspond with flood units and that the $\mathrm{Zr} / \mathrm{Rb}$ ratio provides a robust grain-size proxy (Turner et al., 2015). The ITRAX ${ }^{\mathrm{TM}}$ XRF core scanning, calibrated on laser diffraction grain-size samples, was thus deployed as a grain-size proxy to provide a detailed flood sedimentology from the Manawatu cores.

General trends in grain size may result from changes in proximity to the river channel or the progressive buildup of levees, limiting sediment dispersion across the floodplain (Toonen et al., 2015; Leigh, 2017). Following Jones et al. (2012), in order to account for these geomorphological effects, a $10-\mathrm{cm}$ running filter was used to detrend the data. The detrended data were converted into $Z$-scores to present alongside the $\mathrm{Zr} / \mathrm{Rb}$ ratio to identify flood units in the cores.

\section{Figure 3.}

As part of ITRAX ${ }^{\mathrm{TM}}$ XRF core scanning, contaminant metal levels were also measured. These show consistent trends, and $\mathrm{Cu}$ and $\mathrm{Zn}$ can be used to identify twentieth century floodplain contamination associated with urban and industrial growth (Appendix).

\subsection{Documented historical and late Holocene floods}

Flood chronologies were constrained using a combination of instrumental flow records, documentary sources, and geochemical markers associated with pollution, palynology, and radiocarbon dating. Exploratory use of ${ }^{210} \mathrm{~Pb}$ and ${ }^{137} \mathrm{Cs}$ was deployed on the Hamilton 1 core in order to better constrain the timing of floods recorded in this sedimentary archive with gauged floods. Channel cutoff of Hamilton 1 occurred in A.D. 1937. Figure 4 provides a record of the largest gauged and documented floods in the Manawatu River in each year, as measured at the gauging station in Palmerston North. The Manawatu River has the longest continuous gauging record in New Zealand, extending to 1923, with estimates of flows prior to this made with reference to observation of river levels (Page, 1994). Figure 4 is a synthesised flow record from observations and gauged data that were measured at three sites in close proximity (Fitzherbert 1923-1971, Ruahine Street 1971-1987, and Teachers College 1987present). The three gauging sites can be regarded as a continuous series (Henderson and Diettrich 2007). Flood depths at each palaeochannel have been modelled by Horizons Regional Council (Table 1; J. Bell, pers. comm. 2017). Although not modelled, a flow of $4512 \mathrm{~m}^{3} \mathrm{~s}^{-1}$ is estimated to have an 
annual recurrence interval (ARI) of 500 years, and a flow of $5345 \mathrm{~m}^{3} \mathrm{~s}^{-1}$ is estimated to have an ARI of 2500 years at Teachers College (J. Bell pers. comm. 2017). The modelled ARI of flood depths at each site was used to infer the minimum flood magnitudes needed to produce flood units for each individual sites. Estimation of sediment accumulation rates was feasible where cutoff dates were known or reasonably well constrained by indirect dating $\left({ }^{14} \mathrm{C}\right.$ and palynology; see below).

\section{Figure 4.}

\section{Table 1}

Modelled flood depths for given flood ARIs and magnitudes at each palaeochannel site, in a synthetic situation without stopbanks (flood embankments) but using the current topography; flood magnitudes and return periods were calculated at Teachers College (J. Bell, pers. comm. 2017)

\begin{tabular}{lllllll}
\hline & & \multicolumn{6}{c}{ Approx. modelled depth of flooding (m) } \\
& ARI $(\mathrm{y}):$ & 1 & 2 & 10 & 50 & 100 \\
Palaeochannel & $\mathrm{Q}\left(\mathrm{m}^{3} \mathrm{~s}^{-1}\right):$ & 507 & 1488 & 2462 & 3317 & 3678 \\
\hline Hamilton 1 & 0.5 & 3 & 3 & 3.5 & 4 \\
Karere 2 & $\mathrm{nf}$ & 2 & 2 & 3 & 3.5 \\
Palmy Park & $\mathrm{nf}$ & $\mathrm{nf}$ & 1 & 2 & 3.5 \\
Riverside Drive & $\mathrm{nf}$ & $\mathrm{nf}$ & 1 & 1.5 & 2 \\
Hamilton 2 & $\mathrm{nf}$ & 1 & 1 & 1.5 & 2 \\
Alpaca & $\mathrm{nf}$ & 2 & 2 & 3 & 3.5 \\
Opiki & $\mathrm{nf}$ & $\mathrm{nf}$ & 2.5 & 3 & 3.5 \\
Rocket & $\mathrm{nf}$ & 1 & 1.5 & 2.5 & 3 \\
Napier Rd & $\mathrm{nf}$ & $\mathrm{nf}$ & 1 & 1.5 & 2.5 \\
\hline nf: not flooded. & & & & & &
\end{tabular}

The largest documented flood in 1857 was estimated to have a peak discharge of $4010 \mathrm{~m}^{3} \mathrm{~s}^{-1}$ (Page, 1994). Observations indicate that this flood was generated by an extensive whole-catchment rain event (Page, 1994), possibly in early December, based on a newspaper report of severe flooding in the Turakina catchment $\sim 20 \mathrm{~km}$ to the northwest of the Manawatu watershed (Wellington Independent, 9 December 1857), but no definitive date is available. Six additional floods exceeding $3000 \mathrm{~m}^{3} \mathrm{~s}^{-1}$ have been documented since 1857, these occurred in March 1880, April 1897, June 1902, July 1906, January 1953, and February 2004, indicating that large floods are not related to any particular season.

\subsection{Linking documented floods with the sedimentary record}


Documented floods were linked to the flood sedimentary record by first determining date of cutoff, which provides a secure age for the onset of flood sedimentation in the abandoned channel. At Hamilton 1 exploratory ${ }^{210} \mathrm{~Pb}$ and ${ }^{137} \mathrm{Cs}$ analysis was used to identify peak deposition of ${ }^{137} \mathrm{Cs}$ at ca. 1965 , with no deposition prior to 1952 . Ten-gram samples were taken at 10-cm intervals downcore and indicate that at least the upper $3.0 \mathrm{~m}$ of sediment was deposited post-1952 (Table 2). Analysis was undertaken under contract by the Institute of Environmental Science and Research Ltd, Christchurch. Samples were counted on HPGe (high-purity germanium) detectors with counting time ranging from 48 to 68 hours. For those palaeochannels beyond the stopbanks (embankments providing flood protection) on the inactive floodplain, the last recorded flood is generally 1953. Inferred ages of flood units observed in the cores can reasonably be inferred by comparison with the documented record, taking into account the likelihood of sufficient inundation (cf. Table 1) for the given flood magnitude. Effectively a counting down from the top of the core, and/or up from known date of cutoff, provides a means of assigning flood units to specific documented flood events. This was most straightforward for the few largest events, which were presumed to match rarely occurring coarse flood units. Elevated concentrations of heavy metals in palaeochannel cores reflect pollution associated with the urban growth of Palmerston North from the early twentieth century. Pollen evidence and radiocarbon dating were also used to secure age control.

\section{Table 2}

Radioactive isotope analysis, Hamilton 1 core

\begin{tabular}{llcccc}
\hline $\begin{array}{l}\text { Sample } \\
\text { number }\end{array}$ & $\begin{array}{l}\text { Client } \\
\text { code }\end{array}$ & $\begin{array}{l}\text { Lead-210 } \\
\text { (Bq/kg) }\end{array}$ & $\begin{array}{l}\text { Caesium-137 } \\
\text { (Bq/kg) }\end{array}$ & $\begin{array}{l}\text { Radium-226 } \\
(\mathbf{B q} / \mathbf{k g})\end{array}$ & $\begin{array}{l}\text { Radium-228 } \\
(\mathrm{Bq} / \mathbf{k g})\end{array}$ \\
\hline $2017-1539$ & H1 $0.1 \mathrm{~m}$ & $4.1 \pm 9.7$ & $<0.86$ & $32.5 \pm 2.5$ & $40.2 \pm 3.7$ \\
$2017-1540$ & H1 $0.2 \mathrm{~m}$ & $32.2 \pm 6.2$ & $0.65 \pm 0.25$ & $35.3 \pm 2.9$ & $44.5 \pm 3.5$ \\
$2017-1541$ & H1 $0.3 \mathrm{~m}$ & $37.7 \pm 9.4$ & $<0.88$ & $35.6 \pm 2.8$ & $44.1 \pm 4.0$ \\
$2017-1542$ & H1 $0.4 \mathrm{~m}$ & $32.1 \pm 3.7$ & $0.48 \pm 0.27$ & $42.9 \pm 8.3$ & $53.0 \pm 1.4$ \\
$2017-1543$ & H1 $0.5 \mathrm{~m}$ & $47 \pm 11$ & $<1.3$ & $40.1 \pm 2.9$ & $48.8 \pm 4.0$ \\
$2017-1544$ & H1 $0.6 \mathrm{~m}$ & $47 \pm 14$ & $<1.5$ & $36.2 \pm 3.2$ & $41.8 \pm 4.6$ \\
$2017-1545$ & H1 $0.7 \mathrm{~m}$ & $23.2 \pm 5.3$ & $0.76 \pm 0.40$ & $41.4 \pm 2.8$ & $47.4 \pm 3.7$ \\
$2017-1547$ & H1 $0.9 \mathrm{~m}$ & $39 \pm 11$ & $1.0 \pm 0.53$ & $35.8 \pm 3.6$ & $43.5 \pm 4.6$ \\
$2017-1549$ & H1 1.1 m & $48.6 \pm 7.5$ & $<1.6$ & $36.7 \pm 4.2$ & $48.2 \pm 5.6$ \\
$2017-1551$ & H1 1.3 m & $35.4 \pm 5.5$ & $0.66 \pm 0.47$ & $37.4 \pm 3.6$ & $48.2 \pm 4.7$ \\
$2017-1553$ & H1 1.5 m & $39.7 \pm 7.1$ & $<1.9$ & $40.5 \pm 3.7$ & $52.7 \pm 5.9$ \\
$2017-1555$ & H1 1.7 m & $38 \pm 11$ & $<1.7$ & $40.9 \pm 3.2$ & $48.5 \pm 4.4$ \\
\hline
\end{tabular}




\begin{tabular}{cccccc}
\hline $2017-1557$ & H1 $1.9 \mathrm{~m}$ & $31.2 \pm 5.9$ & $<1.6$ & $35.5 \pm 3.1$ & $42.2 \pm 4.7$ \\
$2017-1559$ & H1 2.1 m & $43.7 \pm 6.4$ & $1.67 \pm 0.56$ & $44.0 \pm 1.3$ & $50.6 \pm 2.3$ \\
$2017-1561$ & H1 2.3 m & $39.0 \pm 8.3$ & $1.95 \pm 0.73$ & $52.1 \pm 3.8$ & $61.5 \pm 5.2$ \\
$2017-1563$ & H1 2.5 m & $39.5 \pm 6.0$ & $1.56 \pm 0.61$ & $43.3 \pm 3.3$ & $52.9 \pm 4.5$ \\
$2017-1565$ & H1 2.7 m & $39.1 \pm 6.2$ & $1.40 \pm 0.52$ & $45.9 \pm 1.3$ & $53.5 \pm 2.3$ \\
$2017-1567$ & H1 2.9 m & $47.6 \pm 7.5$ & $1.90 \pm 0.76$ & $49.4 \pm 3.8$ & $65.7 \pm 5.6$ \\
$2017-1569$ & H1 3.1 m & $37.4 \pm 8.1$ & $1.06 \pm 0.64$ & $44.5 \pm 3.4$ & $55.0 \pm 4.8$ \\
$2017-1571$ & H1 3.3 m & $32.2 \pm 6.6$ & $<1.3$ & $37.1 \pm 2.6$ & $45.3 \pm 3.8$ \\
$2017-1573$ & H1 3.5 m & $47.7 \pm 7.9$ & $<2.2$ & $41.3 \pm 4$ & $54.6 \pm 5.3$ \\
$2017-1575$ & H1 3.7 m & $43.6 \pm 7.7$ & $<2.0$ & $39.2 \pm 4.2$ & $50.9 \pm 5.8$ \\
$2017-1577$ & H1 3.9 m & $40.5 \pm 7.6$ & $<2.0$ & $42.4 \pm 3.7$ & $50.1 \pm 6.2$ \\
\hline
\end{tabular}

\subsection{Palynology}

237 Sediments from fluvial depositional settings are seldom selected for use as palaeovegetation archives

238 given the potential for reworking, the episodic nature of deposition, and the typically large pollen source area. Thus, they are generally of little value for providing detailed reconstructions of local-scale vegetation and climate change. However, they can still provide qualitative indications of broad scale changes in the vegetation of the catchment, such as evidence for periods of major vegetation clearance and the introduction of exotic species, both of which are driven by human activities. Because the timing of Polynesian and European colonisations in New Zealand are well constrained, pollen indicators of these events can therefore provide a rough chronology for deposits in which they occur.

Samples for pollen analysis were taken from unoxidised sediments from cores from five of the study sites, as oxidation in the remainder precluded pollen preservation. For all cores, this excluded the upper 50-100 cm approximately. Samples were processed according to the standard methodology documented in Moore et al. (1991), with residue mounted in silicone oil and examined at 400x magnification under a Zeiss Axiophot microscope.

In New Zealand pollen records, Polynesian and European phases of colonisation are represented by distinctive signals (e.g. Wilmshurst, 1997; McGlone and Wilmshurst, 1999). Polynesian arrival is marked by a decline in native forest pollen and concurrent rise in successional species. European colonisation is marked by further decline in native forest pollen, and the appearance of exotic species introduced for agricultural and horticultural purposes. indicators of the presence of Europeans somewhere within the catchment, thus providing some basic 
chronological control. No definitive signals of deforestation and subsequent succession from either Polynesian or European activities were discernible in the records obtained in this study. This probably reflects muting of the signals of clearance of individual catchments by the continued input of forest pollen from the subcatchments that remain forested.

Summary pollen diagrams for the five sites where pollen was analysed are shown in Fig. 5. As a proof of concept, we chose to investigate Hamilton 1 for pollen, as it provides a benchmark for what we can expect a post-colonisation pollen signal to look like within flood sediments. Pollen of native trees and shrubs are the dominant pollen types recorded despite much of the native forest being cleared during the timespan covered by the Hamilton 1 site. This probably reflects the relatively high pollen production and also the robustness of the pollen grains of some canopy-forming trees present in the remaining native forest in the catchment headwaters. Pollen of introduced pasture herbs (Plantago lanceolata type, Rumex, and Taraxacum) are present in low levels, but consistently so. Pine pollen appears in the middle of the sequence, becoming more abundant towards the top, probably representing the expansion of Pinus radiata forestry in the mid-late twentieth century. Thus, the Hamilton 1 data indicate that a European pollen signal is persevered within these fluvial sediments, but it is considerably more subtle than the signals seen in lake and bog sequences that are only capturing pollen from the immediate vicinity of the site.

\section{Figure 5}

\subsection{Radiocarbon dating}

Table 3 provides details of the radiocarbon dates. Ages were calibrated using OxCal version 4.3.2 (Bronk Ramsey et al., 2017) and the SHCal 13 atmospheric curve (Hogg et al., 2013). Obtaining enough organic matter for radiocarbon dating from these cores was challenging. While most cores contained scattered macroscopic fragments, these were seldom in sufficient concentration to yield enough material for an AMS radiocarbon date. To try to resolve this issue, organic matter from bulk sediment samples from Rocket and Opiki cores was concentrated by removing the clastic matter with hydrofluoric acid. Samples from the Rocket core with $0.85 \mathrm{~m}$ between them were not distinguishable by age. This could reflect inclusion of reworked organic matter in the samples, suggesting bulk concentration is not a viable method. However, it may also simply reflect rapid infilling of the channel. The pollen data from the Rocket core suggest that the entire core accumulated prior to the arrival of humans, which is consistent with the radiocarbon age. However, the Opiki sample was collected from 


\section{Radiocarbon dates}

\begin{tabular}{|c|c|c|c|c|c|c|}
\hline Site & Sample ID & Lab code & Sample material & $\begin{array}{l}\text { Depth } \\
\text { (m) }\end{array}$ & ${ }^{14} \mathrm{C}$ AMS & $\begin{array}{l}\text { Calibrated age } \\
\text { (years) }\end{array}$ \\
\hline Napier Rd & Napier Road & WK-43116 & $\begin{array}{l}\text { Leaves and } \\
\text { twigs }\end{array}$ & $2.27-2.31$ & $2009 \pm 20 \mathrm{BP}$ & $2050-1926$ cal BP \\
\hline \multirow[t]{2}{*}{ Rocket } & Rocket OC1 & WK-43117 & Bulk organics & $3.85-3.90$ & $2663 \pm 20 \mathrm{BP}$ & $2831-2775$ cal BP \\
\hline & Rocket OC2 & WK-43118 & Bulk organics & 2.99-3.04 & $2696 \pm 20 \mathrm{BP}$ & 2850-2792 cal BP \\
\hline Opiki & Opiki & WK-43119 & Bulk organics & $2.50-2.54$ & $1722 \pm 20 \mathrm{BP}$ & $1745-1585 \mathrm{cal} \mathrm{BP}$ \\
\hline
\end{tabular}
seems an overestimation. This could also be the result of older organic matter in the dated sample or perhaps a hiatus in sedimentation. The Napier Road sample comprised macroremains (leaves, twigs, etc.) and can be considered more reliable, and ${ }^{14} \mathrm{C}$ ages are consistent with the pollen data.

\section{Table 3}

297

\section{Results and Interpretation}

Of the nine cores extracted from the Manawatu palaeochannels, four were located on the current floodplain (Fig. 6; Appendix: Figs. A1-4). The remaining five sites were located beyond stopbanks in the protected floodplain (Fig. 7; Appendix: Figs. A5-9), which no longer has flood-related sedimentation. Stopbanks in the Lower Manawatu Flood Protection Scheme are rated as providing '500-year' flood protection (Watson, pers. comm., 2017). A schematic (Fig. 8) summarises the results from the cores described in detail in this section and displays their relative position on the floodplain.

The observed flow record of the Manawatu (Fig. 4) has been mapped to each major flood event detected using the $\mathrm{Zr} / \mathrm{Rb}$ ratio and $\mathrm{Z}$-score, taking into account the age of the palaeochannel and available chronology in the core (pollen, radiocarbon ages, and historical information). Based on the modelled flow depths (Table 1), floods with magnitudes around and $>2000 \mathrm{~m}^{3} \mathrm{~s}^{-1}$ will potentially leave a sediment signature at all sites (cf. Table 1). Smaller floods will also inundate the more proximal channels. Hamilton 1 and Karere 2 (Fig. 6; Figs. A1-2) are located within the Manawatu stopbanks and potentially provide a record of every flood since stopbank construction in the early 1960s; however, 
the upper metre of these cores was not scannable (too brittle with heavy bioturbation and oxidation), and the past ca. 20 years of record is missing (Fig. 8).

\section{Figure 6.}

\section{Figure 7.}

\section{Figure 8.}

\subsection{Active floodplain sites}

Hamilton 1, Karere 2, Riverside Drive, and Napier Road cores are located in the currently active floodplain. Full results are presented in the Appendix. Figures 6 and 8 summarise the floods inferred from Z-score results (Appendix) and correlates these to the documented flood record. Results for Hamilton 1, Riverside Drive, and Napier Road are described in detail below (see also Fig. 8). Karere 2 is described in the Appendix as it is very similar to Hamilton 1, being an historical cutoff from 1888 (Page and Heerdegen, 1985).

\subsubsection{Hamilton 1}

The oldest flood in Hamilton 1 dates to 1937, when this bend was abandoned (Page and Heerdegen, 1985), and cutoff was coincident with a flood $>2000 \mathrm{~m}^{3} \mathrm{~s}^{-1}$ (cf. Fig. 6). The site was flooded recently in 2015 and 2004. The coarser and deeper part of the palaeochannel sequence probably accumulated rapidly, when an open connection with the active channel existed (cf. Toonen et al., 2012), potentially including the years before a full cutoff was established. Within-channel sediments in the lower part of the core demonstrate an open connection with the active channel for some short, but unknown, period. During this period coarse sediment could be conveyed into the abandoning channel. This did not necessarily occur during the earliest annual maximum peak discharges of 1941 and 1942 but could equally have occurred during higher flows throughout the year because of (periodic) connection with the channel, allowing rapid deposition to take place. Because of this connection, $35 \mathrm{~cm}$ of sedimentation during a single year or flood in this depositional context is not unusual. At the time when the channel was fully disconnected (1953 and 1956), variability in grain size and sedimentation 
rates has to be related to sediment deposited by overbank floods or to pulses of sedimentation during a single large event (cf. Macklin et al., 1992). Annual peak floods may all have been preserved in the period directly following the initial abandonment in 1937, as all inundated this site (cf. Table 1). Therefore, the flood unit at $4.33 \mathrm{~m}$ matches with the $1941 \mathrm{flood}$, which also exceeded $2000 \mathrm{~m}^{3} \mathrm{~s}^{-1}$. Average sedimentation rate since abandonment is $58 \mathrm{~mm} / \mathrm{y}, 455 \mathrm{~cm}$ between A.D. 2015 and 1937, with higher rates near the bottom and toward the top of the sequence based on general trends in channel fill grain sizes and ${ }^{137} \mathrm{Cs}$ data (cf. Table 2). Therefore, the missing scanned section in the upper part of the core is estimated to represent at least $\sim 25$ years. Hence, recent large events (e.g. $3500 \mathrm{~m}^{3} \mathrm{~s}^{-}$ 1 flood in February 2004 and $2500 \mathrm{~m}^{3} \mathrm{~s}^{-1}$ flood in July 1992) are not present in the record. Floods exceeding $2500 \mathrm{~m}^{3} \mathrm{~s}^{-1}$ occurred in May 1941, January 1953, July 1956, and March 1965, which according to Table 1 would inundate the site to a depth of $3 \mathrm{~m}$. An initial chronology is provided in Fig. 6. The coarse-grained part of the sequence has probably accumulated during the initial flood events after abandonment and the majority with the large 1941 flood $\left(2605 \mathrm{~m}^{3} \mathrm{~s}^{-1}\right)$. After ca. 1941, the channel became less connected from the main river, resulting in dramatic reduction of channel fill grain size. If the larger peaks $(>2.5 \sigma)$ relate to floods with a discharge $>2000 \mathrm{~m}^{3} \mathrm{~s}^{-1}$, then the latest flood to be recorded locally would be the October 1988 event. This fits the previous assumption that at least the last 25 years was missing. The large March $1965\left(2744 \mathrm{~m}^{3} \mathrm{~s}^{-1}\right)$ and January $1953\left(3176 \mathrm{~m}^{3} \mathrm{~s}^{-1}\right)$ events are presumably also registered as peaks in grain-size proxy (Z-score). Based on the inferred ages at 1 and $4 \mathrm{~m}$, respectively 1980s and 1940s, these events should be present in the central part of the core. The two largest peaks in grain size can be found between 2 and $3 \mathrm{~m}$ depth. Despite the greater peak discharge of the 1953 event, the Z-score is slightly smaller than the 1965 flood. The grain size of flood deposits is dependent on the shape of the hydrograph and on hysteresis effects on river sediment load, not simply related to flood magnitude. Peaks in grain size tentatively match with peak flows exceeding $2000 \mathrm{~m}^{3} \mathrm{~s}^{-1}$ (Fig. 6). Smaller peaks were left unassigned because at this site these can relate to any discharge exceeding just $500 \mathrm{~m}^{3} \mathrm{~s}^{-1}$ (Table 1 ) and because these relatively minor annual peak discharges or second-ranked annual events are not considered in this study.

\subsubsection{Riverside Drive}

Riverside Drive (Figs. 6, A3) was abandoned before 1859 (inferred from position of the river surveyed in 1859; Manawatu Catchment Board, 1982) and last inundated in 2004 (personal observation, ICF). This site is located in an area of floodplain without stopbanks and is confined by high fluvial terraces (cf. Fig. 2). The 2004 flood is likely the Z-score peak in the upper $0.2 \mathrm{~m}$. The entire core consists of an overbank sequence without major changes in grain size (below $1 \mathrm{~m}$, deposits are a little coarser, probably reflecting proximity to the active channel). High $\mathrm{Zn}$ and $\mathrm{Cu}$ in the upper $5 \mathrm{~cm}$ are associated 
with modern pollution (Fig. A3). Several other distinct high peaks of Zn are located in the upper metre, and a single high peak of $\mathrm{Pb}$ was measured around $75 \mathrm{~cm}$. These might be related to specific pollutionspillage events that must have occurred after the 1880s when industrialisation of the region commenced (Manawatu Catchment Board, 1982). If the 2004 event $\left(3515 \mathrm{~m}^{3} \mathrm{~s}^{-1}\right)$ is related to a $\mathrm{Zr} / \mathrm{Rb}$ Z-score of $>2 \sigma$, previous events of a similar Z-score are likely associated with events exceeding 3000 $\mathrm{m}^{3} \mathrm{~s}^{-1}$ as well. Based on this assumption, peaks can be correlated with the large floods of January 1953 $\left(3176 \mathrm{~m}^{3} \mathrm{~s}^{-1}\right)$, the events of May $1907\left(3340 \mathrm{~m}^{3} \mathrm{~s}^{-1}\right)$, June $1902\left(3800 \mathrm{~m}^{3} \mathrm{~s}^{-1}\right)$, and April $1897\left(3333 \mathrm{~m}^{3} \mathrm{~s}^{-}\right.$ $\left.{ }^{1}\right)$, which form a cluster of large floods at the turn of the twentieth century, and March 1880 (3980 $\left.\mathrm{m}^{3} \mathrm{~s}^{-1}\right)$. The position of the 1880 event is consistent with an increase in contaminant metal concentrations associated with early industrialisation and urbanisation in the Manawatu catchment. Before 1880 the discharge record is incomplete and the correlation becomes more tentative. However, the 1857 event $\left(4010 \mathrm{~m}^{3} \mathrm{~s}^{-1}\right)$ is the largest event recorded and is likely associated with the coarsest flood units at c. $1.5 \mathrm{~m}$ depth. If the same accumulation rates apply for the deeper part of the core, this flood record goes back to the early nineteenth century and contains several historically unknown floods of large magnitudes (in the realm of $3000-4000 \mathrm{~m}^{3} \mathrm{~s}^{-1}$ ).

\subsubsection{Napier Road}

Napier Road (Figs. 6, A4) is the most distal palaeochannel in the upper part of the study reach, adjacent to the Late Pleistocene river terrace. It was abandoned at an indeterminate pre-1859 date (inferred from river position in 1859; Manawatu Catchment Board, 1982), and a radiocarbon age of 2050-1926 cal. BP at 2.27-2.31 m (Table 2) suggests a likely 2-3 ka record of flooding at this site. Pollen of European introduced herbs (specifically Plantago and Taraxacum) dating to ca. A.D. 1840 appears between 161 and $156 \mathrm{~cm}$ depth within the Napier Road core. Radiata pine (Pinus radiata) is first recorded at c. $75 \mathrm{~cm}$ depth, representing the expansion of pine forestry in New Zealand in the midtwentieth Century. In more recent flood events, although not stopbanked, the site is probably disconnected from floods by a main (elevated) road, so the $1953\left(3176 \mathrm{~m}^{3} \mathrm{~s}^{-1}\right)$ flood is likely the most recent to inundate the site (no river flooding in 2004). The lower part of the core is relatively coarse with many flood units, the middle section $(60-200 \mathrm{~cm})$ is silty with several thick flood units in the top, and the upper $60 \mathrm{~cm}$ is very fine organic clay, commensurate with a disconnection from river floods, and likely reflects ponding from local surface and stormwater runoff. The units between 60 and 100 $\mathrm{cm}$ represent large floods and probably relate to the cluster of floods at the turn of the twentieth century. This is consistent with elevated Zn concentrations in these units (Fig. A4).

Older (>2050-1926 cal. BP) coarse deposits toward the base of the Napier Road core are likely to reflect channel proximity at this time, rather than indicating large floods analogous to the situation 
described at Hamilton 1. However, a period of significantly enhanced river activity recorded in the North Island from ca. 2400-2100 cal. BP (Fuller et al., 2015), suggests that large floods (ca. $>3000 \mathrm{~m}^{3}$ $\left.\mathrm{s}^{-1}\right)$ may have occurred during this period. Importantly, the evidence from the Napier Road core is consistent with the meta-analysis of Fuller et al., (2015).

\subsection{Inactive floodplain sites}

Palmy Park, Hamilton 2, Alpaca, Opiki, and Rocket are located beyond stopbanks on the protected floodplain; they are no longer affected by current overbank sedimentation. Full results are presented in the Appendix (Figs A5-9). Figure 7 summarises the floods inferred from the Z-score results (Appendix) and correlates these to the documented flood record. Results for Palmy Park, Hamilton 2, and Rocket are described in detail below. Alpaca is described in the Appendix for the sake of brevity.

\subsubsection{Palmy Park}

Palmy Park (Figs. 7, A5) records Manawatu floods between the 1960s and at some point prior to 1859 (inferred from river position in 1859; Manawatu Catchment Board, 1982); however, following 1960s stopbank construction, inundation still occurred associated with overspill from the Mangaone tributary that flows within the western $\operatorname{limb}$ of this palaeochannel. Pollen data indicate European impact starts between 100 and $132 \mathrm{~cm}$, ca. A.D. 1840. The upper section was too brittle for ITRAX ${ }^{\mathrm{TM}}$ scanning and heavily bioturbated. At $130 \mathrm{~cm}$ a very clear and rapid transition from sandy material to overbank clays is observed. Few flood units are visible, but those present are very clear with thick units, reflected in the $Z$-score plots. High peaks of $\mathrm{Zn}$ and $\mathrm{Pb}$ occur around $1 \mathrm{~m}$, and in the upper metre a clear trend of increasing contaminant metal concentration $(\mathrm{Zn}, \mathrm{Ni}, \mathrm{Cu}, \mathrm{Pb})$ is visible. The earlier peaks probably relate to the onset of industrialisation in the late nineteenth century, while the general increase is later (probably mid-twentieth century related to the expansion of Palmerston North). The large events clustered between 100 and $120 \mathrm{~cm}$ can be matched with large floods at the turn of the twentieth century (i.e., 1907, 1902 and 1897). Events predating this period have produced significantly larger peaks in the Z-score proxy grain-size record-notably around $130 \mathrm{~cm}$ and below $160 \mathrm{~cm}$. Based on the palynological information and historical maps (abandonment of the channel before 1859), these peaks likely relate to extreme floods that occurred in the nineteenth century, probably those of 1880 and 1857 . Several other large floods can be observed in the record before the flood-intense episode centred on the 1850 s.

\subsubsection{Hamilton 2}


Hamilton 2 (Figs. 7, A6) is located beyond stopbanks and away from tributary influences. The channel was abandoned (shortly) before 1859 (inferred from river position in 1859; Manawatu Catchment Board, 1982), and the last inundation was the 1953 flood prior to stopbank construction. Several clear trends were visible in channel-fill sedimentology. First, at the bottom a stepwise abandonment of the site with progressively finer overbank deposits is evident. Around $2.50 \mathrm{~m}$ a coarsening of material may relate to relocation of the active river closer to the site. Large floods are recorded $(Z>4)$, but events near the bottom of the core may have been amplified by the open channel connection conveying coarser material. No clear trends in contaminant metal concentration were observed, but a slight increase in $\mathrm{Zn}$ levels occurred in the upper $2 \mathrm{~m}$. Although 1953 should have been the last flood to occupy the site, the first coarse flood unit is only found at c. $1 \mathrm{~m}$ depth. Above this level, the infilling might relate to more recent local runoff. The two events around $1 \mathrm{~m}$ depth are therefore probably the $1956\left(2513 \mathrm{~m}^{3} \mathrm{~s}^{-1}\right)$ and $1953\left(3176 \mathrm{~m}^{3} \mathrm{~s}^{-1}\right)$ floods. A flood-rich episode between 1898 and 1907 can be related to an interval with frequent coarse flood units between 2 and $2.5 \mathrm{~m}$. Other smaller peaks between 1953 and 1907 relate to floods of lesser magnitude (2000-2500 ms $\left.\mathrm{s}^{-1}\right)$, such as 1949, 1947, $1941,1936,1926,1924,1917$, and 1913 . The peak at $3.5 \mathrm{~m}$ has a relative magnitude appropriate for the 1880 event, while one of the coarsest flood units near the base of the channel fill is likely to be related to the 1857 flood. This matches the inferred age of abandonment before 1859 .

\subsubsection{Opiki}

456

Opiki (Figs. 7, A8) was abandoned before 1859 (inferred from river position in 1859; Manawatu Catchment Board, 1982) and records floods up to 1953 when it was disconnected from the active floodplain by stopbank construction. The pollen biomarker at ca. $2.25 \mathrm{~m}$ recording exotic species (post-European settlement) appears to conflict with the radiocarbon age of 1745-1585 cal. BP at a depth of c. $2.5 \mathrm{~m}$ in this core. European indicators (Rumex, Taraxacum) first appear between 225 and $218 \mathrm{~cm}$ in the Opiki core, with pine pollen appearing at $180 \mathrm{~cm}$. No sedimentary or pedogenic evidence for a hiatus has been observed, suggesting incorporation of aged carbon in the radiocarbon date. This is the only site positioned downstream of the Oroua confluence. The channel fill shows a typical abandonment sequence, with initially coarse deposits that grade into fine overbanks. Some variability in general overbank coarseness could be attributed to changes in the position of the active river, although given the low energy fluvial environment in this part of the system changes could also reflect discrete inputs from the nearby Oroua tributary. A number of large events are visible in the upper metre, with a flood unit very near to the surface. Because the stopbanks were constructed in the 469 1960s, this is very likely to be the 1953 event. Apart from the 1953 flood, a cluster of events between 70 and $90 \mathrm{~cm}$ are probably the 1897,1902 , and 1907 floods. The older part of the record is difficult to 
resolve; nonetheless, such information is useful in demonstrating that very large floods also occurred in the period before large-scale deforestation.

Rocket (Figs. 7, A9) is the most distal palaeochannel in the low-gradient reach of the river and records floods up to 1953. It was abandoned before 1859 (inferred from river position in 1859; Manawatu Catchment Board, 1982). The radiocarbon age of 2850-2792 cal. BP suggests a likely $\sim 3$ ka record of floods from this location. No European pollen indicators were observed in the samples from the Rocket site, suggesting that this site was mostly infilled prior to ca. A.D. 1840. However, notably the upper $50 \mathrm{~cm}$ of the record was not sampled as a consequence of oxidation. Two bulk radiocarbon dates yielded ages of $2831-2775 \mathrm{cal}$ BP at 3.85-3.90 m depth and 2850-2792 cal BP at 2.99-3.04 m depth. Deposits are all finely laminated overbank sediments, with gravel occurring below $5 \mathrm{~m}$ (not scanned). The upper $3.5 \mathrm{~m}$ is more fine-grained with a gradual coarsening upward, possibly related to the river migrating toward the site. Larger floods are evenly distributed throughout the core. High Zn concentrations linked to contamination were recorded at c. $50 \mathrm{~cm}$. If the coarse flood unit around 1.5 $\mathrm{m}$ is the 1857 event, this sedimentary sequence provides evidence of several other large floods in the realm of $3500-4000 \mathrm{~m}^{3} \mathrm{~s}^{-1}$ in the earlier part of the nineteenth century and potentially also in the eighteenth century.

Z-scores are site dependent, even for sites in the same reach of a river system, because they represent an offset compared with an average value, which differs given proximity effects and specific dynamics of channel infilling. Therefore, to compare flood Z-scores between locations, a statistical recurrence time is more useful. Additionally, a recurrence time can be compared with statistics of the gauged series, and allows us to test the relationship between major documented floods (ca. 1850-2015) in the Manawatu with the palaeoflood series. In the overbank palaeoflood sequence for the local records, where we have best time control and event dating, we regressed the $Z$-scores versus their statistical occurrence-time period of overbank section divided by the number of events exceeding a certain $Z$ score (Eq. 1):

$$
R I=\frac{y}{n}
$$


501

502

503

504 To avoid jumps in the data (if for example a gap exists in Z-scores series, leading to unequally spaced

where RI is Recurrence interval (years), $y$ is time span in overbank section, $n$ is number of events exceeding a given $Z$-score.

\begin{abstract}
data) and to get a realistic estimate on the RI of the largest Z-score measured, we fitted a regression
\end{abstract} function through the estimated RIs vs. Z-scores. From these curves (Table 4) we recalculated the RI of all measured Z-scores. This procedure worked for all sites with the exception of Palmy Park, where a strong fining-upward trend complicates the by-proxy relative magnitude identification of discrete large flood events on the basis of grain size. The results of this analysis demonstrate a good relationship between recurrence estimates based on the discharge series and the recurrence estimates based on the Manawatu palaeoflood record (Fig. 9). This confirms the robustness of using grain size as a proxy for estimating the relative magnitudes of palaeofloods in the Manawatu.

\section{Table 4}

Z-score versus recurrence time regression analysis for overbank deposits ca. 1800-2015 for the Manawatu palaeoflood sites.

\begin{tabular}{|c|c|c|c|c|c|}
\hline Site & $\begin{array}{l}\text { Regression } \\
\text { function }\end{array}$ & $R^{2}$ & $\begin{array}{l}\text { Registration period A.D. } \\
\text { (used for correlation) }\end{array}$ & $\begin{array}{l}\text { Avg SAR } \\
(\mathrm{mm} / \mathrm{y})\end{array}$ & $\begin{array}{l}\text { Core section } \\
\text { (cm) }\end{array}$ \\
\hline Alpaca & $\left.0.1040 e e^{(2.1811 x}\right)$ & 0.99 & c. $1800-1900$ (100 years) & 17 & $35-200$ \\
\hline Hamilton 1 & $0.0163 e^{(1.9793 x)}$ & 0.90 & 1942-1991 (49 yearrs) & 54 & $120-385$ \\
\hline Hamilton 2 & $0.0864 e^{(1.2764 x)}$ & 0.97 & c. $1870-1970$ (100 years) & 45 & $0-450$ \\
\hline Karere 2 & $0.1392 e^{(1.2642 x)}$ & 0.97 & $1897-2000$ (103 years) & 26 & $0-265$ \\
\hline Napier Road & $1.9411 e^{(0.5766 x)}$ & 0.97 & c. $1800-2015$ (215 years) & 8 & $30-200$ \\
\hline Opiki & $\left.0.7596 e^{(0.6035 x}\right)$ & 0.79 & c. $1855-1955$ (100 years) & 15 & $0-150$ \\
\hline Palmy Park & $0.0161 e^{(3.1969 x)}$ & 0.94 & c. $1890-1970$ (80 years) & 9 & $65-130$ \\
\hline $\begin{array}{l}\text { Riverside } \\
\text { Drive }\end{array}$ & $0.2272 e^{(1.908 x)}$ & 0.98 & 1860-2005 (145 years) & 10 & $0-150$ \\
\hline Rocket & $\left.0.1156 e e^{1.4627 x}\right)$ & 0.99 & 1960-1850 (110 years) & 12 & $30-160$ \\
\hline
\end{tabular}

516 


\section{Discussion and Conclusions}

520

521

522

523

524

525

526

527

528

529

530

531

532

533

534

535

536

537

538

539

540

541

542

543

544

545

546

547

548

549

The sedimentary archive provided by palaeochannels in the lower Manawatu floodplain provides a high resolution and a long-term record of historic and prehistoric floods in the Manawatu catchment. This record is the first to provide an indicator of timing and of magnitude of discrete, storm-generated flood events in New Zealand in the late Holocene. The records from the distal palaeochannel at Napier Road (Figs. 6, 8), which has secure age control back as far as 2000 cal. YBP, suggests that historical floods are among the largest to have occurred in the Manawatu in the past 2000 years. Furthermore, of these floods, the largest estimated in excess of $4000 \mathrm{~m}^{3} \mathrm{~s}^{-1}$ in 1857 has not yet been surpassed and may well represent the largest in $\sim 3000$ years. The timing of such large flood events in the mid-and late-1800s is consistent with observations elsewhere in New Zealand where for example widespread deforestation in the Motueka catchment in the 1870 s was followed by severe flooding and substantial erosion (Beatson and Whelan 1993). A link between land cover change and changing flood magnitude and frequency is likely, since clearance of trees from a catchment increases the catchment runoff coefficient. Furthermore the end of the nineteenth century has been classified as a period of enhanced river activity in New Zealand (Fuller et al.,, 2015), associated not only with human disturbance of catchments but also enhanced storminess (Norton et al., 1989) and neoglacial activity (Schaefer et al., 2009); and an enhanced southwesterly flow across New Zealand has been reconstructed during the Little Ice Age in New Zealand (Lorrey et al., 2014). Land cover changes and climate regime would appear to be favourable in generating large floods in the Manawatu catchment at this time.

Nonetheless, what the record presented here does imply is the absence of any particularly large or catastrophic flood event in the Manawatu during the past 3000 years based on the nine sites in the 20-km-long study reach. Several '200-year' floods $\left(\sim 4500 \mathrm{~m}^{3} \mathrm{~s}^{-1}\right)$ are likely, but nothing larger. The implication of this is that the extended Manawatu flood series indicates a relatively stable flood regime in this catchment or an upper physical boundary to meteorological events. This limit may be imposed by the Manawatu Gorge, which acts as a 'throttle' on floods generated from the eastern subcatchments (Manawatu Catchment Board, 1983), with the result that floodwaters pond to the east of the Gorge. The Manawatu flood series presented here does not appear to have been marked by notable variability in flood magnitude and frequency during the last two millennia. This may reflect the nature of the catchment, straddling as it does the coherent precipitation regions of the southwestern North Island and eastern North Island (Mullan 1998) whose boundary is the axial ranges, which may insulate the lower reaches of the catchment from extreme floods. However, comparison 
with the CPF curve for the North Island does indicate that a number of flood-rich periods occurred in the past 2000 years (Fig. 6), at ca. 2300, 2100, 1700-1600, 750, 450-350, 150, and 80 cal. YBP.

The floodplain sedimentary archive presented here shows an acceleration in floodplain sedimentation following European forest clearance in the catchment. At the Rocket site, a sedimentation rate between ca. 870 B.C. and AD 1857 of $0.57 \mathrm{~mm} \mathrm{y}^{-1-}$ compares with a rate of $9.49 \mathrm{~mm} \mathrm{yr}^{-1}$ after 1857 (cf. Fig. 8). Extremely high rates of sedimentation were observed in the stopbanked floodplain at Hamilton $1\left(58 \mathrm{~mm} \mathrm{y}^{-1}\right)$, where stopbanks constrain floodplain sedimentation resulting in aggradation and the development of a perched floodplain. This greatly exceeds more modest rates of $9.5 \mathrm{~mm} \mathrm{y}^{-1}$ recorded since 1857 at Riverside Drive, where the floodplain is not stopbanked and flood deposits are more widely dispersed. This relatively modest sedimentation rate $\left(9.5 \mathrm{~mm} \mathrm{y}^{-1}\right)$ corresponds with floodplain sedimentation rates elsewhere in New Zealand following post-settlement catchment disturbance (Richardson et al., 2014). The implications for palaeoflood reconstruction are that a very high resolution of floods is preserved since the 1800s, but probably only the largest floods register a clear sedimentary signature in the record prior to this, particularly in distal cores. This weaker sedimentary signature, together with limited means of constraining ages in these cores, presents challenges for palaeoflood reconstruction in the Manawatu record.

As a proof of concept, the results presented in this paper demonstrate that high resolution flood records can be reconstructed from XRF core scanning. This also provides a useful insight into understanding magnitude and frequency of very large floods, which is essential for flood risk assessment in a changing climate.

\section{Acknowledgements}

Funding for this research was provided by the 2015 Massey University Research Fund to ICF, MGM and KAH. WHJT was supported by a NWO Rubicon grant (825.14.005). We thank David Feek (Physical Geography Technician, SAE) for assistance with fieldwork. lan Saunders (Aberystwyth University) is acknowledged for supporting the grain-size analyses. Horizons Regional Council are thanked for providing the LiDAR data set (Andrew Steffert), flood modelling data (Jon Bell), and additional archive information (Jeff Watson). We thank the reviewers tasked with reviewing this manuscript, and the especially helpful comments of an anonymous referee and the Editor, Richard Marston.

\section{References}

Beatson, K.E. \& Whelan, H. (1993). The River Flows on: Ngatimoti Through Flood and Fortune. K. Beatson \& H. Whelan. 
Clement, A.J., Sloss, C.R. \& Fuller, I.C. (2010). Late quaternary geomorphology of the Manawatu coastal plain, North Island, New Zealand. Quaternary International, 221, 36-45.

Clement, A.J.H., Fuller, I.C. \& Sloss, C. (2017). Facies architecture, morphostratigraphy, and sedimentary evolution of a rapidly-infilled Holocene incised-valley estuary: the lower Manawatu valley, North Island New Zealand. Marine Geology, in press.

Cowie CA (1957). Floods in New Zealand 1920-1953. The Soil Conservation and Rivers Control Council, Wellington.

Ely, L.L. (1997). Response of extreme floods in the southwestern United States to climatic variations in the late Holocene. Geomorphology, 19, 175-201.

Foulds, S.A. \& Macklin, M.G. (2016). A hydrogeomorphic assessment of twenty-first century floods in the UK. Earth Surface Processes and Landforms, 41, 256-270.

Fuller, I.C., Macklin, M.G. \& Richardson, J.M. (2015). The geography of the Anthropocene in New Zealand: Differential river catchment response to human impact. Geographical Research, 53, 255-269.

Fuller, I.C., Basher, L. \& Macklin, M.G. (2016). Natural Hazards, in: Jellyman P, Davie TJA, Pearson CP, Harding JS (Eds) Advances in New Zealand Freshwater Science, 415-443.

Graettinger, A.H., Manville, V. \& Briggs, R.M. (2010). Depositional record of historic lahars in the upper Whangaehu Valley, Mt. Ruapehu, New Zealand: implications for trigger mechanisms, flow dynamics and lahar hazards. Bulletin of volcanology, 72, 279-296.

Henderson, R. \& Diettrich, J. (2007). Statistical analysis of river flow data in the Horizons Region. NIWA Christchurch, New Zealand.

Hicks, D.M., Shankar, U., McKerchar, A.I., Basher, L., Lynn, I., Page, M. et al. (2011). Suspended sediment yields from New Zealand rivers. Journal of Hydrology (New Zealand), 81-142.

Hogg, A.G., Hua, Q., Blackwell, P.G., Niu, M., Buck, C.E., Guilderson, T.P. et al. (2013). SHCal13 Southern Hemisphere calibration, 0-50,000 years cal BP. Radiocarbon, 55, 1889-1903.

Jones, A.F., Macklin, M.G. \& Brewer, P.A. (2012). A geochemical record of flooding on the upper River Severn, UK, during the last 3750years. Geomorphology, 179, 89-105.

Kiem, A.S., Franks, S.W. \& Kuczera, G. (2003). Multi-decadal variability of flood risk. Geophysical Research Letters, 30.

Leigh, D.S., 2017. Vertical accretion sand proxies of gaged floods along the upper Little Tennessee River, Blue Ridge Mountains, USA. Sedimentary Geology, https://doi.org/10.1016/j.sedgeo.2017.09.007

LoRe, G., Fuller, I.C., Tarolli, P. \& Sofia, G. High-resolution mapping of Manawatu palaeochannels. New Zealand Geographer, in review.

Lorrey, A., Fauchereau, N., Stanton, C., Chappell, P., Phipps, S., Mackintosh, A. et al. (2014). The Little Ice Age climate of New Zealand reconstructed from Southern Alps cirque glaciers: a synoptic type approach. Climate Dynamics, 42, 3039.

Macklin, M. G., Rumsby, B. T., \& Newson, M. D. (1992). Historical floods and vertical accretion of finegrained alluvium in the Lower Tyne Valley, northeast England. Dynamics of gravel-bed rivers, 573-589.

Macklin, M.G., Fuller, I.C., Jones, A.F. \& Bebbington, M. (2012). New Zealand and UK Holocene flooding demonstrates interhemispheric climate asynchrony. Geology, 40, 775-778.

MANAWATU CATCHMENT BOARD, 1982: 'History of the Manawatu River and the Manawatu Catchment Board'. Manawatu Catchment Board Report No. 42.

MANAWATU CATCHMENT BOARD, 1983: 'Lower Manawatu scheme review, 1950- 1982 and proposed works, 1983-1988'. Manawatu Catchment Board Report No. 50.

Manville, V. (2004). Palaeohydraulic analysis of the 1953 Tangiwai lahar; New Zealand's worst volcanic disaster. Acta Vulcanologica, 16, 1000-1015.

Manville, V. \& Hodgson, K. (2011). Paleohydrology of volcanogenic lake break-out floods in the taupo volcanic zone, new zealand. Natural and Artificial Rockslide Dams, 519-541. 
Manville, V. \& Wilson, C.J.N. (2004). The 26.5 ka Oruanui eruption, New Zealand: A review of the roles of volcanism and climate in the post-eruptive sedimentary response. New Zealand Journal of Geology and Geophysics, 47, 525-547.

Manville, V., White, J., Houghton, B. \& Wilson, C. (1999). Paleohydrology and sedimentology of a post1.8 ka breakout flood from intracaldera Lake Taupo, North Island, New Zealand. Geological Society of America Bulletin, 111, 1435-1447.

Manville, V., Newton, E.H. \& White, J.D. (2005). Fluvial responses to volcanism: resedimentation of the 1800a Taupo ignimbrite eruption in the Rangitaiki River catchment, North Island, New Zealand. Geomorphology, 65, 49-70.

McGlone, M. and Wilmshurst, J. (1999) Dating initial Maori environmental impact in New Zealand. Quaternary International 59: 5-16.

Moore PD, Webb JA, Collinson ME (1991) Pollen Analysis. 2nd ed. Blackwell Scientific Publications, London.

Mullan, A. (1998). Southern Hemisphere sea-surface-temperatures and their contemporary and lag association with New Zealand temperature and precipitation. International Journal of Climatology, 18, 817-840.

Munoz, S.E., Gruley, K.E., Massie, A., Fike, D.A., Schroeder, S. \& Williams, J.W. (2015). Cahokia's emergence and decline coincided with shifts of flood frequency on the Mississippi River. Proceedings of the National Academy of Sciences, 112, 6319-6324.

NIWA (2017) National and Regional Climate maps, available at: https://www.niwa.co.nz/climate/national-and-regional-climate-maps/manawatu. Accessed 19 July 2017.

Norton, D., Briffa, K. \& Salinger, M. (1989). Reconstruction of New Zealand summer temperatures to 1730 AD using dendroclimatic techniques. International Journal of Climatology, 9, 633-644.

Page, C.F., 1994. Manawatu River at Fitzherbert. Manawatu Wanganui Regional Council Report 94/EXT/160.

Page, K. \& Heerdegen, F.G. (1985). Channel change on the lower Manawatu River. New Zealand Geographer, 41, 35-38.

Pillans, B., 1986. A late Quaternary uplift map for the North Island, New Zealand. Royal Society of New Zealand Bulletin 24, 409-417.

Richardson, J., Fuller, I., Macklin, M., Jones, A., Holt, K., Litchfield, N. et al. (2013). Holocene river behaviour in New Zealand: response to regional centennial-scale climate forcing. Quaternary Science Reviews, 69, 8-27.

Richardson, J., Fuller, I.C., Holt, K.A., Litchfield, N.J \& Macklin, M.G. (2014). Rapid post-settlement floodplain accumulation in Northland, New Zealand. Catena, 113, 292-305.

Schaefer, J.M., Denton, G.H., Kaplan, M., Putnam, A., Finkel, R.C., Barrell, D.J. et al. (2009). Highfrequency Holocene glacier fluctuations in New Zealand differ from the northern signature. science, 324, 622-625.

Toonen, W., Winkels, T., Cohen, K., Prins, M. \& Middelkoop, H. (2015). Lower Rhine historical flood magnitudes of the last 450years reproduced from grain-size measurements of flood deposits using End Member Modelling. Catena, 130, 69-81.

Toonen, W.H.J., Middelkoop, H., Konijnendijk, T.Y.M., Macklin, M.G. \& Cohen, K.M. (2016). The influence of hydroclimatic variability on flood frequency in the Lower Rhine. Earth Surface Processes and Landforms, 41, 1266-1275.

Toonen, W.H.J., Foulds, S.A., Macklin, M.G. \& Lewin, J. (2017). Events, episodes, and phases: Signal from noise in flood-sediment archives. Geology, 45, 331-334.

Turner, J.N., Jones, A.F., Brewer, P.A., Macklin, M.G. \& Rassner, S.M. (2015). Micro-XRF Applications in Fluvial Sedimentary Environments of Britain and Ireland: Progress and Prospects. In: MicroXRF Studies of Sediment Cores. Springer, pp. 227-265. 
Vale, S., Fuller, I., Procter, J., Basher, L. \& Smith, I. (2016). Characterization and quantification of suspended sediment sources to the Manawatu River, New Zealand. Science of the Total Environment, 543, 171-186.

Wellman, H.W., 1972. Rate of horizontal fault displacement in New Zealand. Nature 237, 275-277. Whitehouse, I.E., Pearce, A.J., 1992. Shaping the mountains of New Zealand, in: Soons, J.M., Selby, M.J. (Eds.), Landforms of New Zealand. Longman Paul, Auckland, pp. 144-160.

Willis G 2014. Managing natural hazards in New Zealand: towards more resilient communities: a thinkpiece. October 2014. Available at: http://www.lgnz.co.nz/assets/Publications/Managing-natural-hazards-LGNZ-think-piece.pdf (accessed 5 July 2017).

Wilmshurst, J. (1997). The impact of human settlement on vegetation and soil stability in Hawke's Bay, New Zealand. New Zealand Journal of Botany 35: $97-111$.

\section{List of Figures}

Fig. 1. Manawatu catchment: (A) North Island location, (B) primary sub-catchments and location of Palmerston North (the focus of this study), (C) catchment land use, (D) catchment geology (after Vale et al., 2016). Rectangle shows extent of study area (cf. Fig. 2).

Fig. 2. I. Airborne laser scanning (LiDAR) derived terrain surface of the lower Manawatu valley in the vicinity of Palmerston North (data supplied courtesy of Horizons Regional Council). The urban area of Palmerston North is outlined. Photos $(A-C)$ give examples of palaeochannels: $(A)$ is located at the northern margin of the floodplain adjacent to a late Pleistocene river terrace (Napier Road); (B) is the former McRaes Bend, which was artificially cut in the 1950s for city flood protection; (C) is Hamilton's lagoon in the naturally unconfined floodplain (Hamilton 2). II. Larger-scale image of the Manawatu floodplain showing location of core sites and cross sections of the floodplain, with cored palaeochannels labelled.

Fig. 3. Grain size comparisons. (A) $D_{50}: D_{90}$ relationships for all sites; (B) comparison between normalised $\mathrm{Zr} / \mathrm{Rb}$ ratio and $D_{50}$; (C) grain size data for an exemplar core (Hamilton 1, cf. Fig. 2), plotting $D_{50}$ and $D_{90}$ downcore and percentage clay, silt, and sand.

Fig. 4. Documented floods (largest annual daily maximum) in the Manawatu River at Palmerston North. Data supplied by Horizons Regional Council.

Fig. 5. Summary pollen diagrams for Hamilton 1, Napier Road, Palmy Park, and the Rocket and Opiki sites. Data are displayed as relative proportions calculated against the sum of all dryland pollen, which includes trees, shrubs, and herbs (natives and exotics) but excludes ferns.

Fig. 6. Active floodplain sites: Z-score results for Hamilton 1, Karere 2, Riverside Drive, and Napier Road compared with documented and gauged flood record for the Manawatu at Palmerston North, 
attributed to the most likely flood event on the basis of radiometric age, pollen, contaminant metals, and cartographic sources. Example core photos are included. CPF curve (from Fuller et al., 2015) shown and linked to the Napier Road record using the ${ }^{14} \mathrm{C}$ age of 2050-1926 cal. YBP and the A.D. 1840 pollen age estimate. Flood-rich periods are identified as peaks exceeding 0.75 .

Fig. 7. Inactive floodplain sites: Floods inferred using Z-scores for Palmy Park, Hamilton 2, Alpaca, Opiki, and Rocket compared with one another and the documented flood record, attributed to the most likely flood event on the basis of radiometric age, pollen, contaminant metals, and cartographic sources. The longer records from the upstream active floodplain sites (Riverside Drive and Napier Road) are also included for comparison. Example core photos are included.

Fig. 8. Schematic diagram showing the relative floodplain position and broad sedimentology of cores described in detail in the text. Dates of inferred floods are labelled.

Fig. 9. Recurrence time estimates of major floods based on observed discharge series (open circles) compared with reconstructed palaeofloods using Z-score regression as a proxy for grain size (diamonds). The Z-scores presented are an average derived from all sites in the Manawatu, excluding Palmy Park.

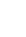




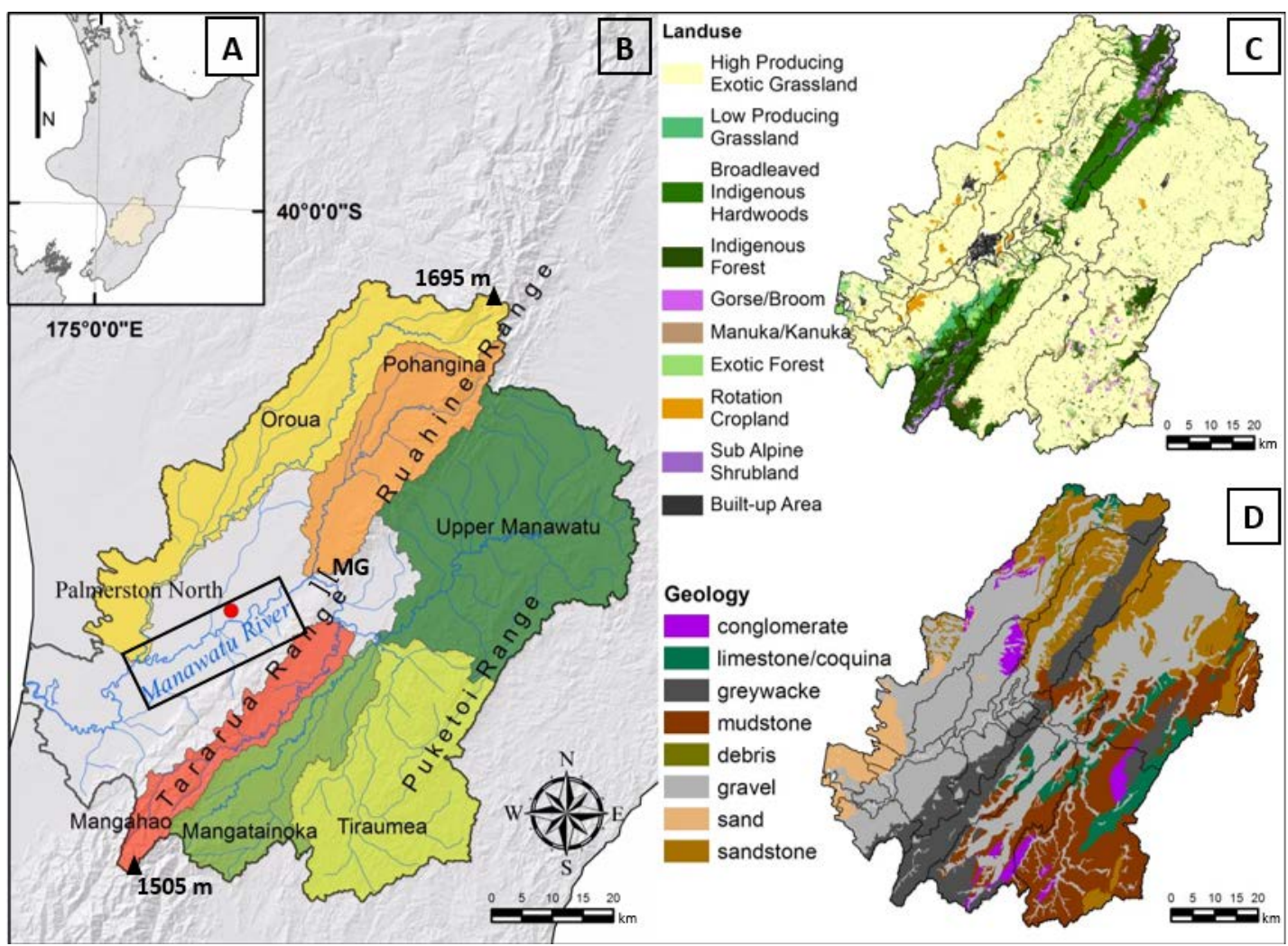

Figure 1. 


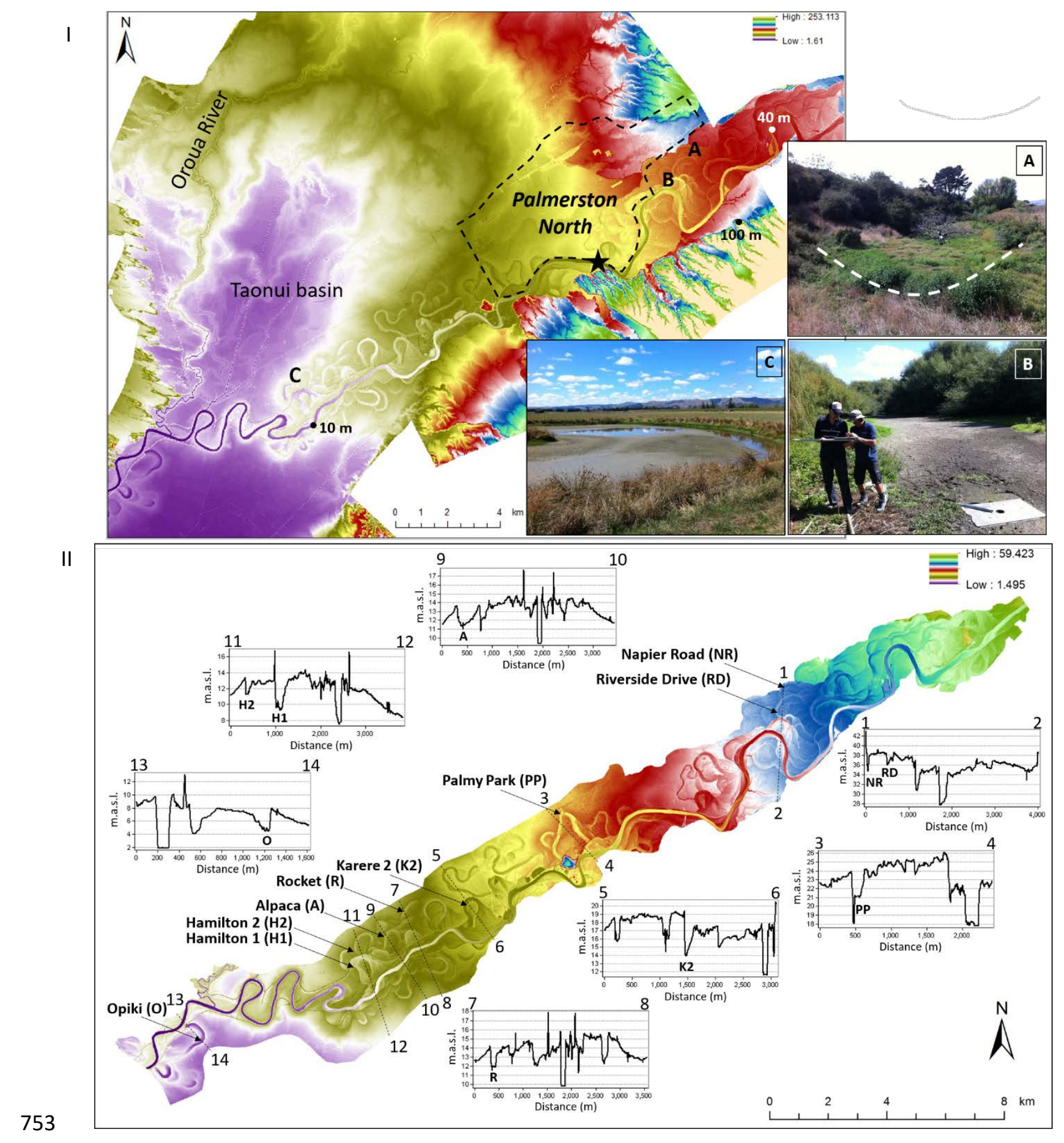

$754 \quad$ Figure 2. 

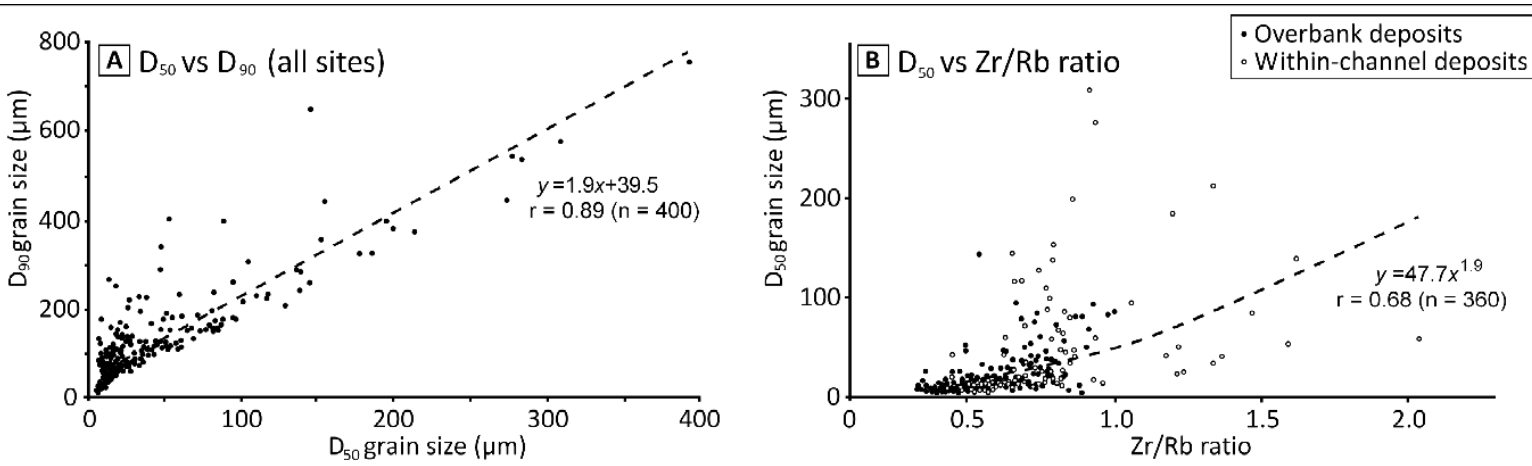

C Hamilton1 ( $\mathrm{H} 1)$ grain-size data
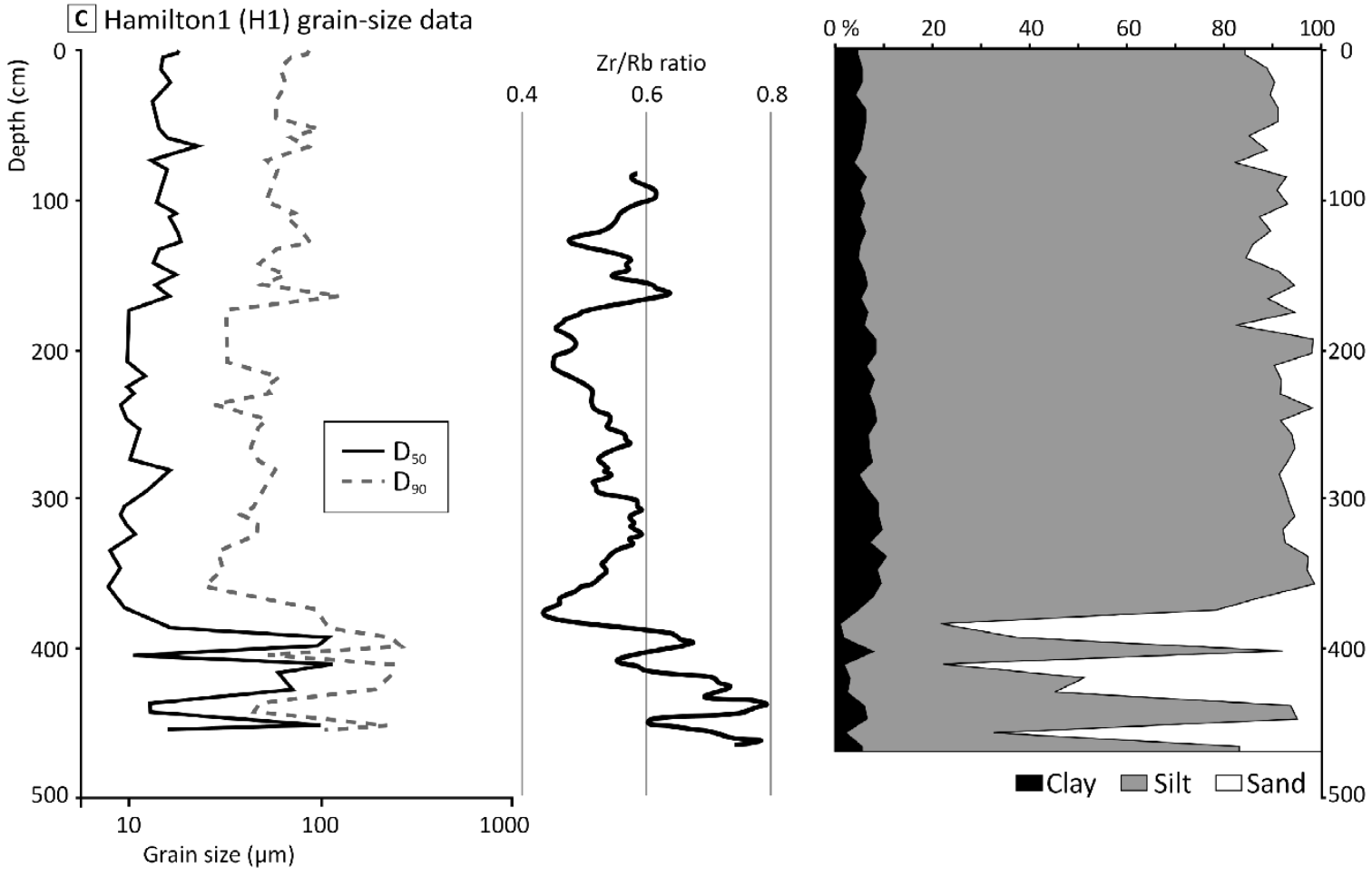

Figure 3. 


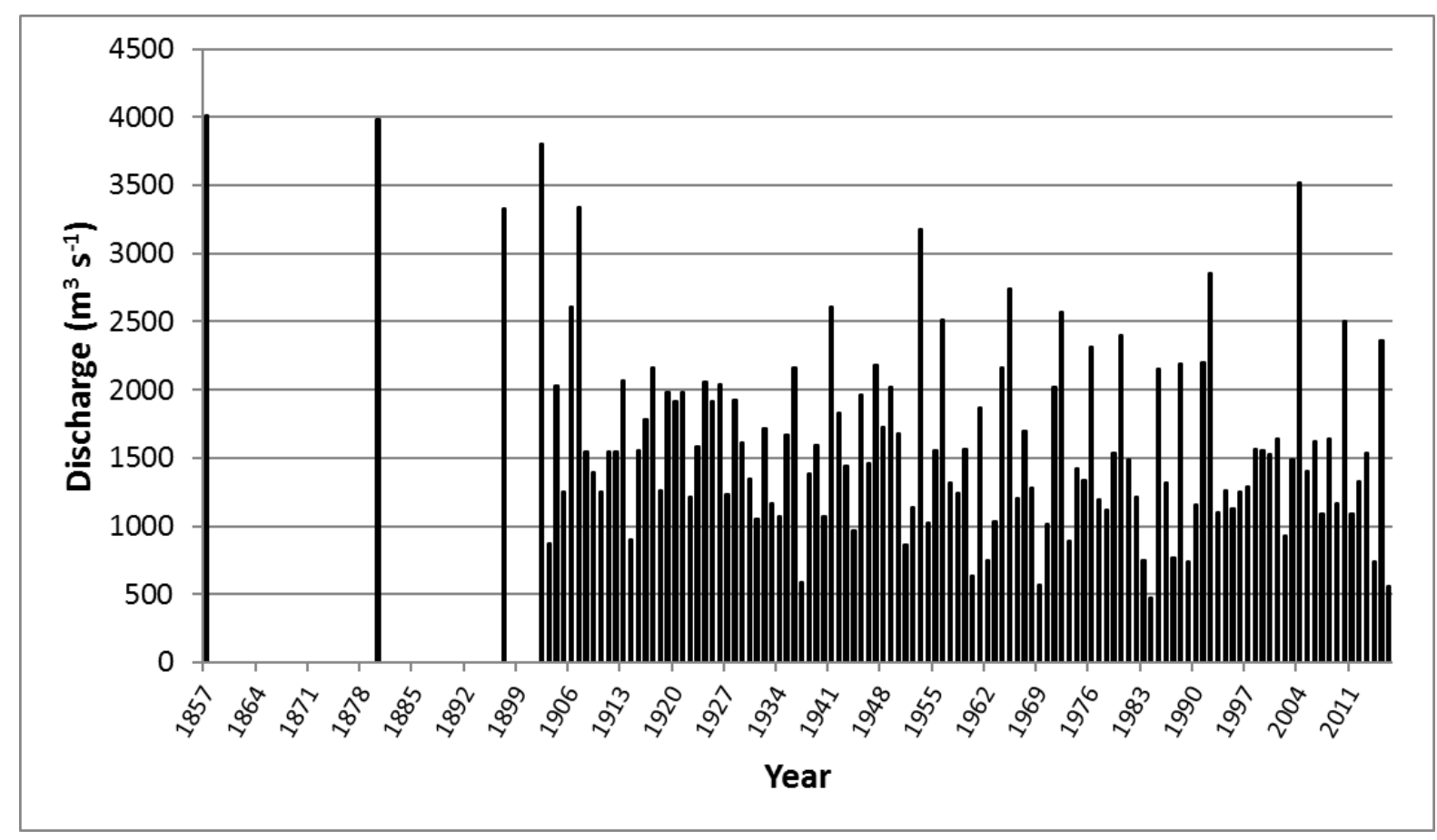

759

760

Figure 4.

761 
(A) Hamilton 1

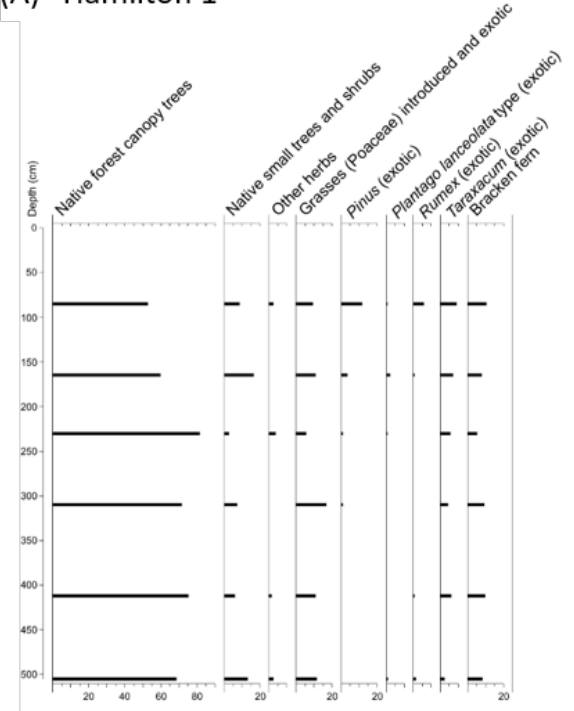

(C) Palmy Park

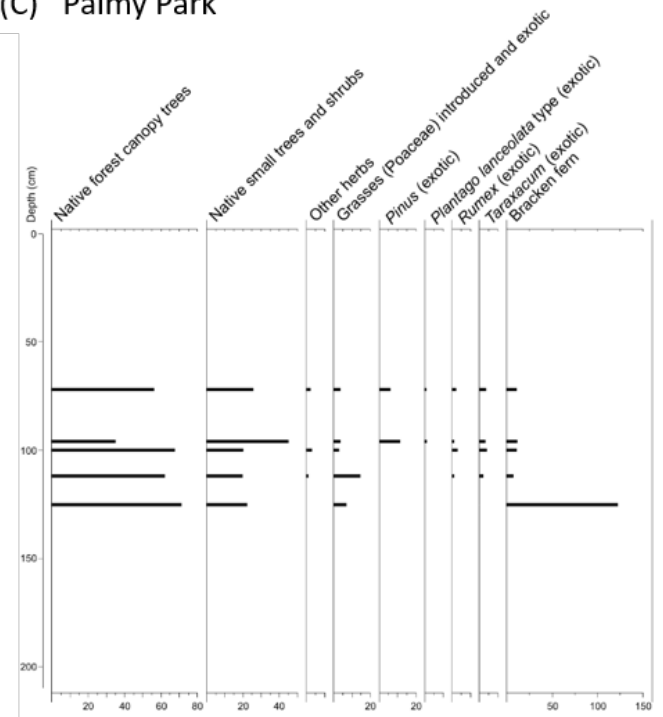

(B) Napier Road

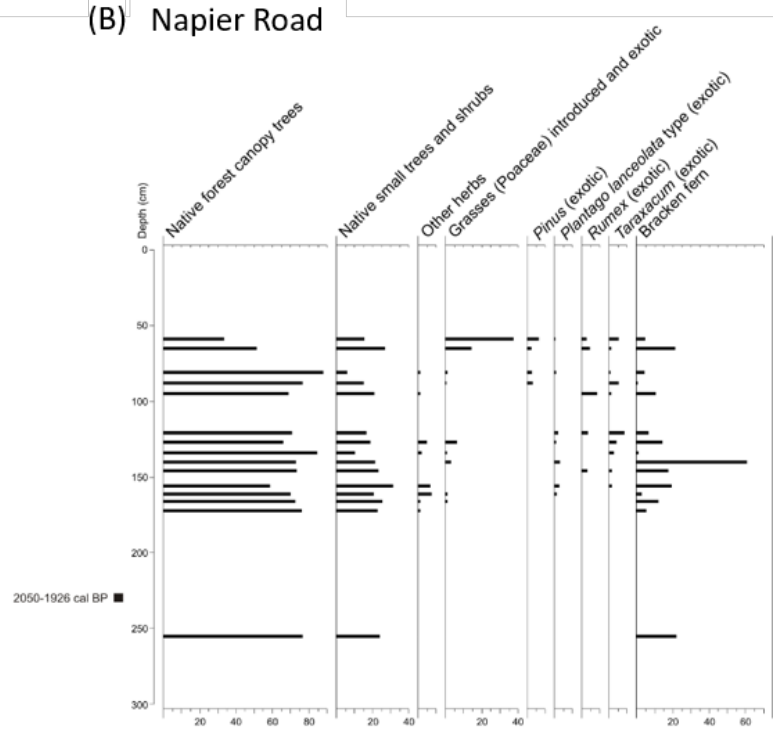

(D) Rocket

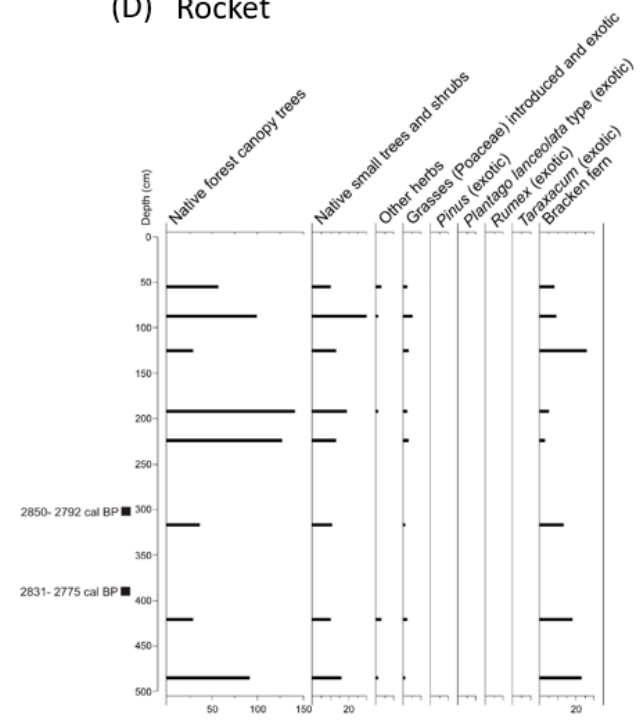

(E) Opiki

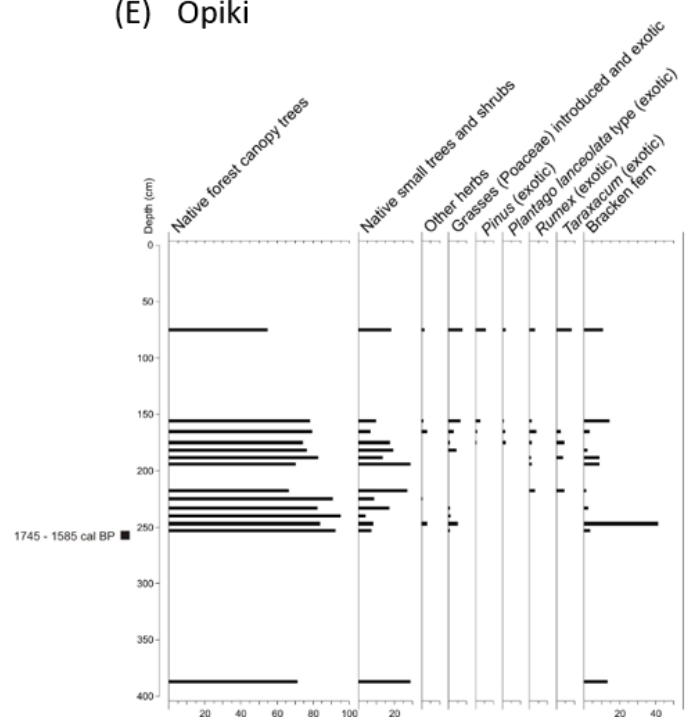

Figure 5. 

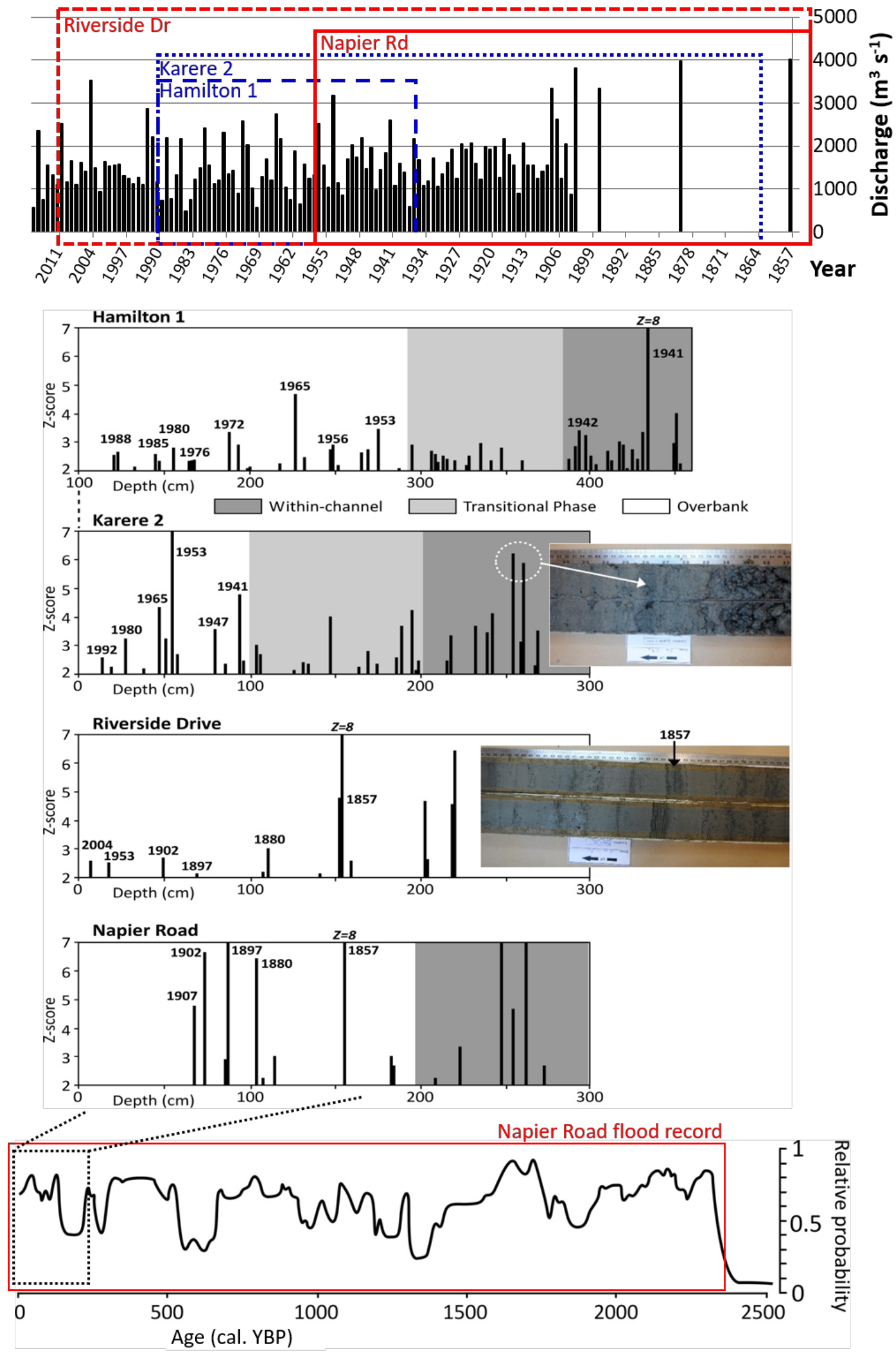

Figure 6. 

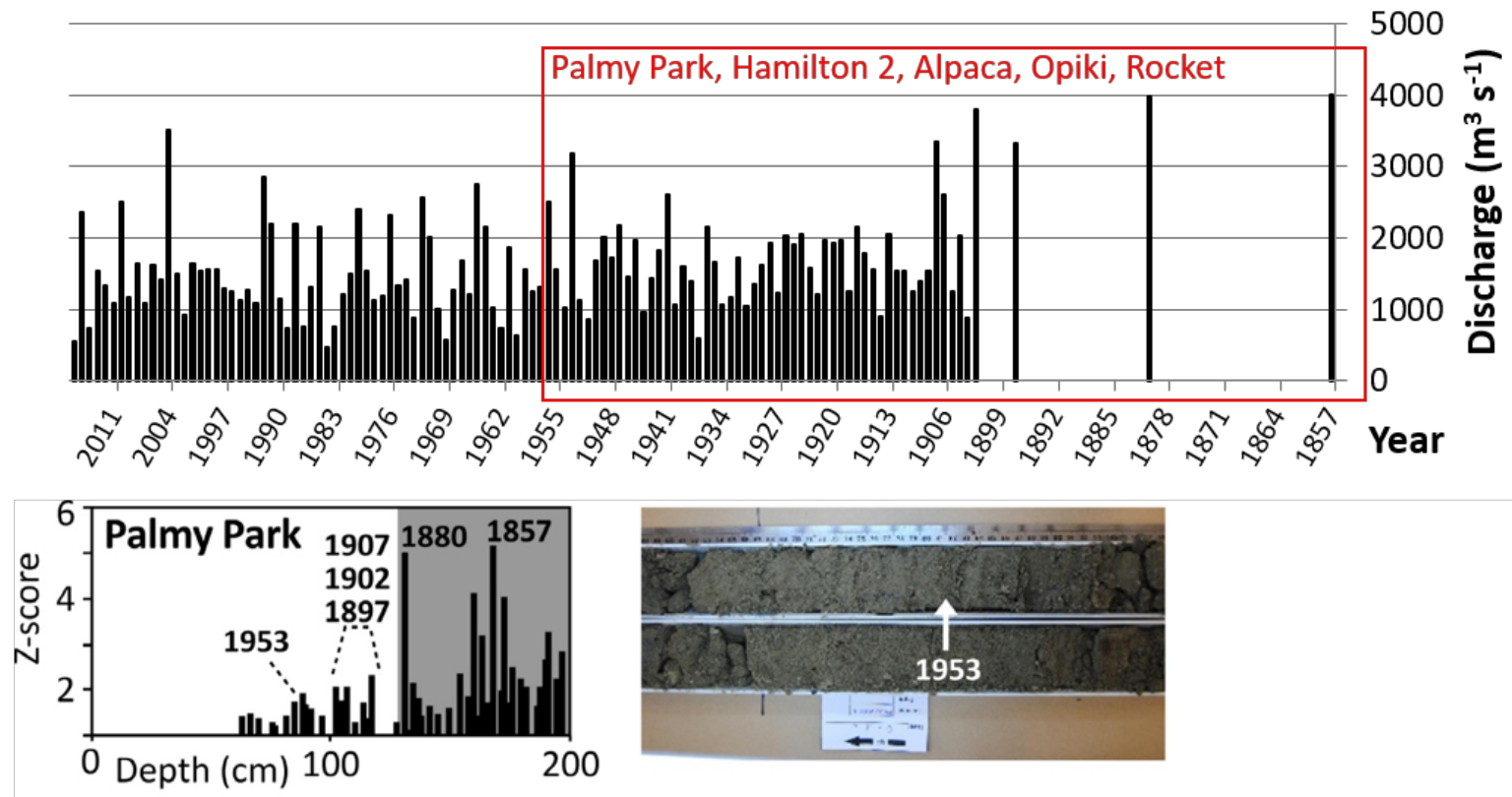

Within-channel Transitional Phase Overbank
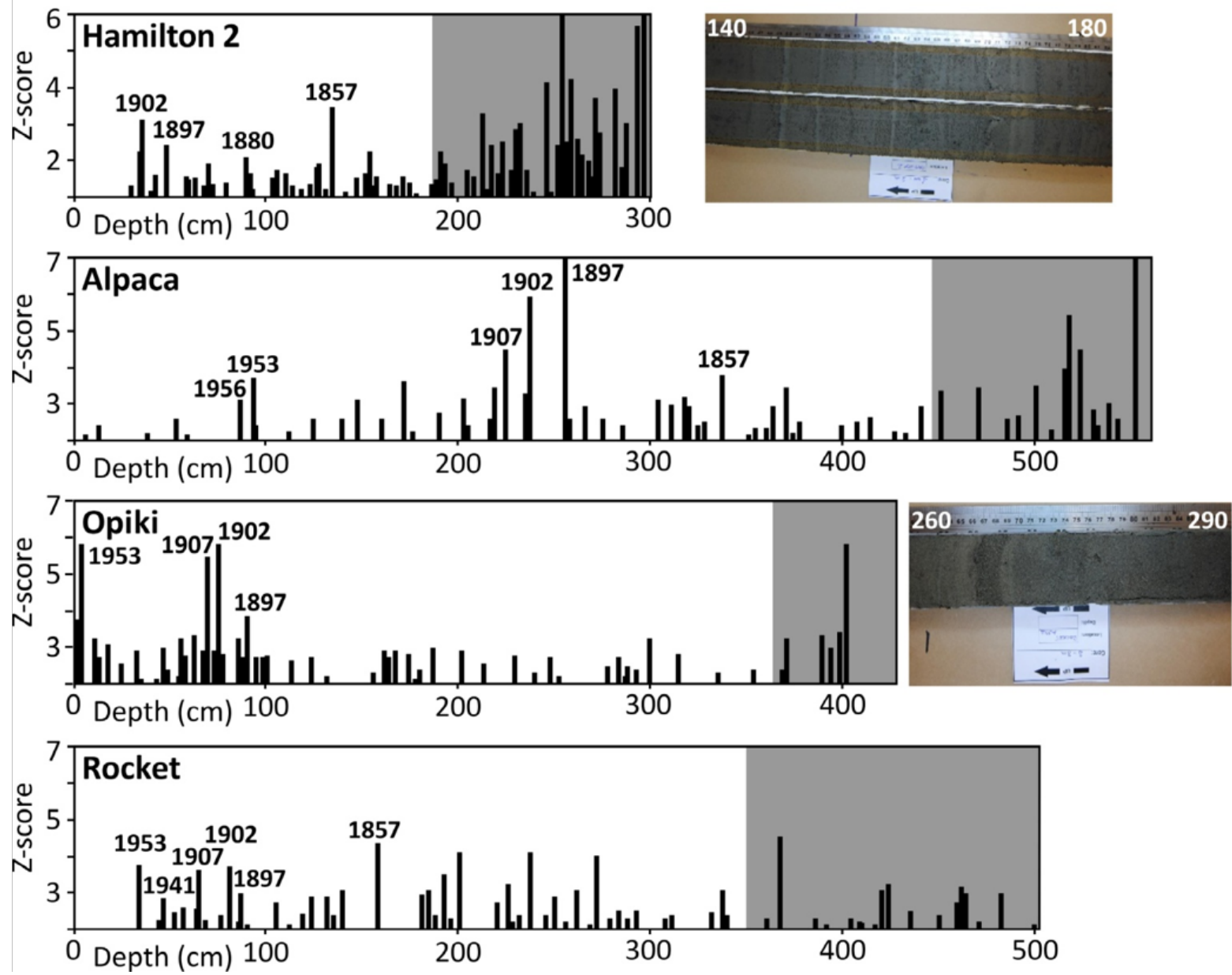

Figure 7. 


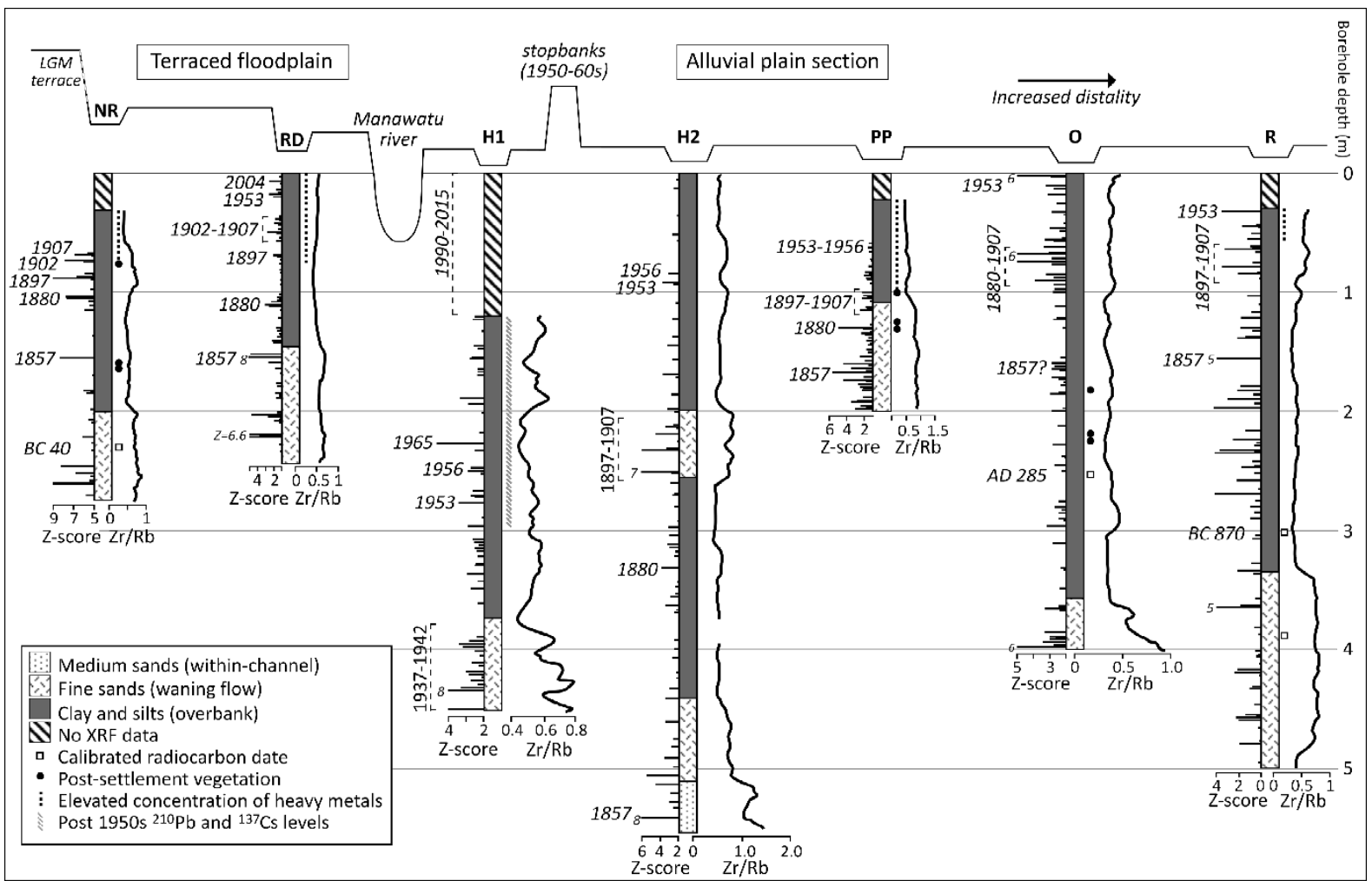

Figure 8.

771

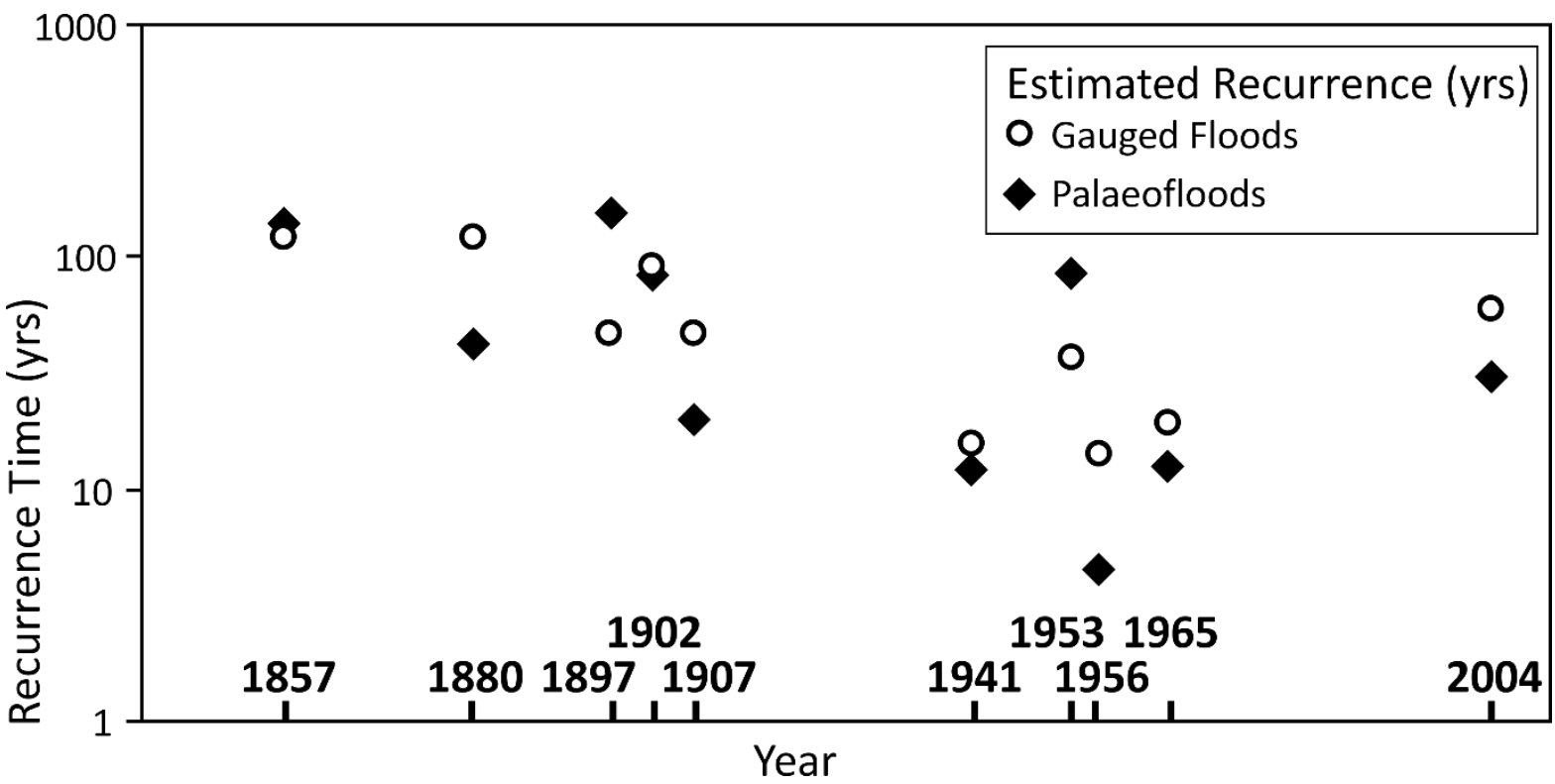

Figure 9. 

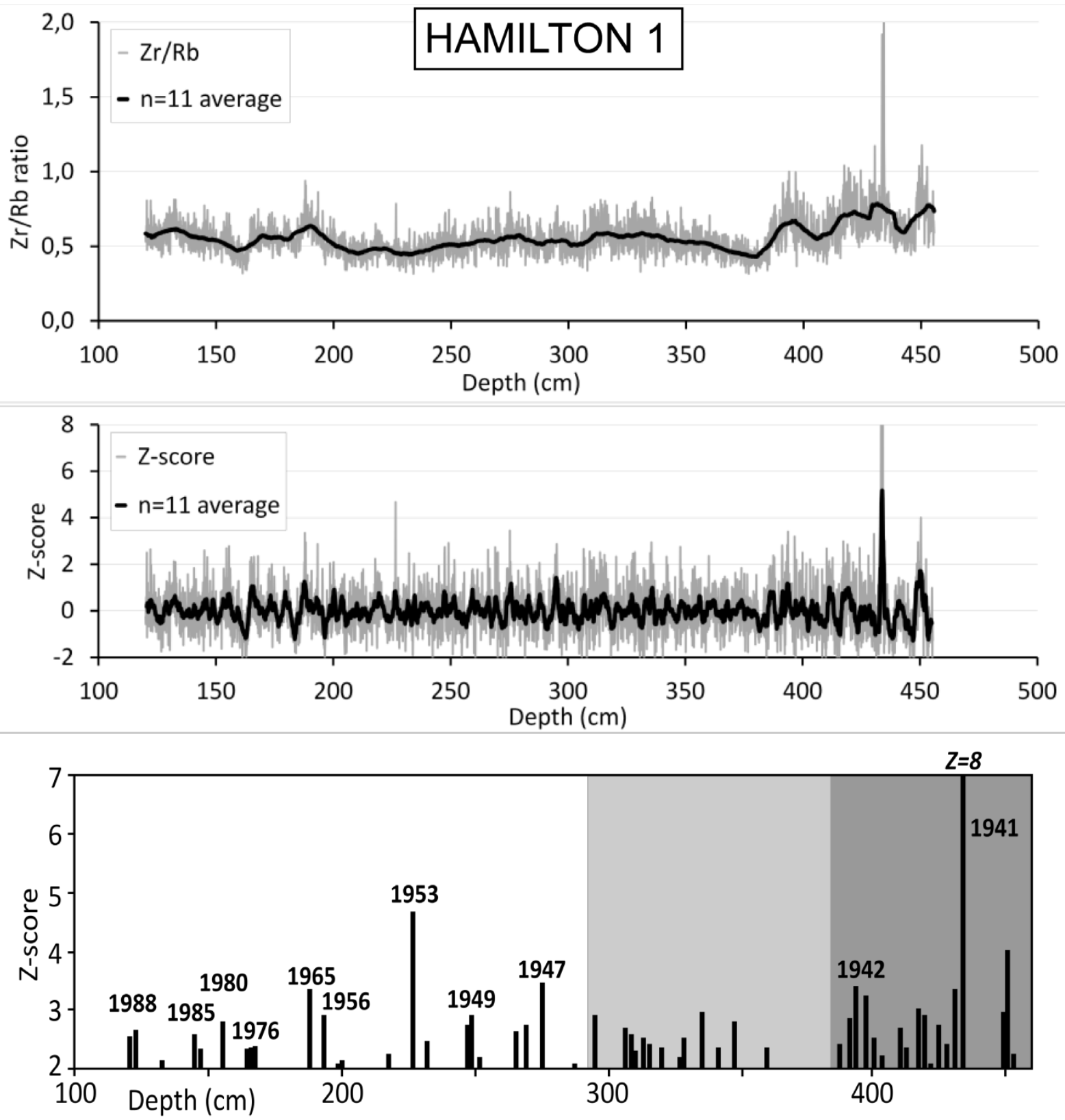

777 Within-channel Transitional Phase Overbank 

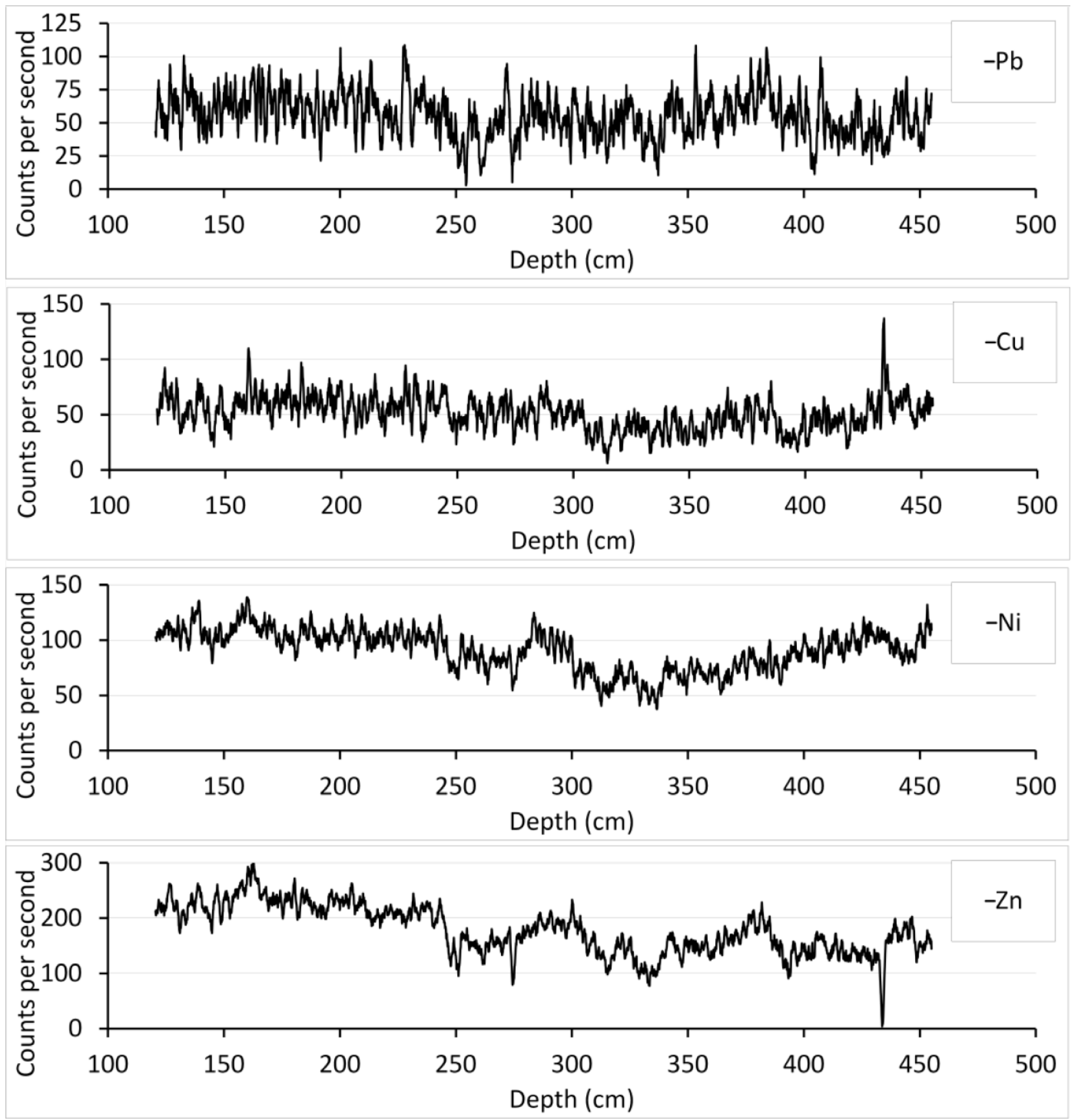

Figure A1 Hamilton 1 core: $\mathrm{Zr} / \mathrm{Rb}$ ratio, Z-score, inferred floods, heavy metal geochemistry ( $\mathrm{Pb}, \mathrm{Cu}$, $\mathrm{Ni}, \mathrm{Zn})$. 
Karere 2 was abandoned shortly after 1860 (exact date not known, Manawatu Catchment Board, 1982 ) and can be flooded by small ( 2 yr ARI floods) (Table 1). Below $200 \mathrm{~cm}$ fairly coarse deposits gradually fine upward into overbank sediments in the upper $120 \mathrm{~cm}$. Many smaller flood units were detected (Fig. 7). Gradually increasing Zn levels in the upper metre are partly related to an increase in fines, and cannot be considered as an indication for increasing pollution levels in the catchment. It is difficult to assign ages to flood deposits. The peak around $50 \mathrm{~cm}$ may well be the 1953 event. Peaks in the deeper part of the core might relate to the flood-rich episode between 1897-1907. Despite being actively flooded in recent decades because of the position of the palaeochannel inside the stopbanks, no flood unit could be related to the 2004 event as the recent units at this site are relatively finegrained.

795
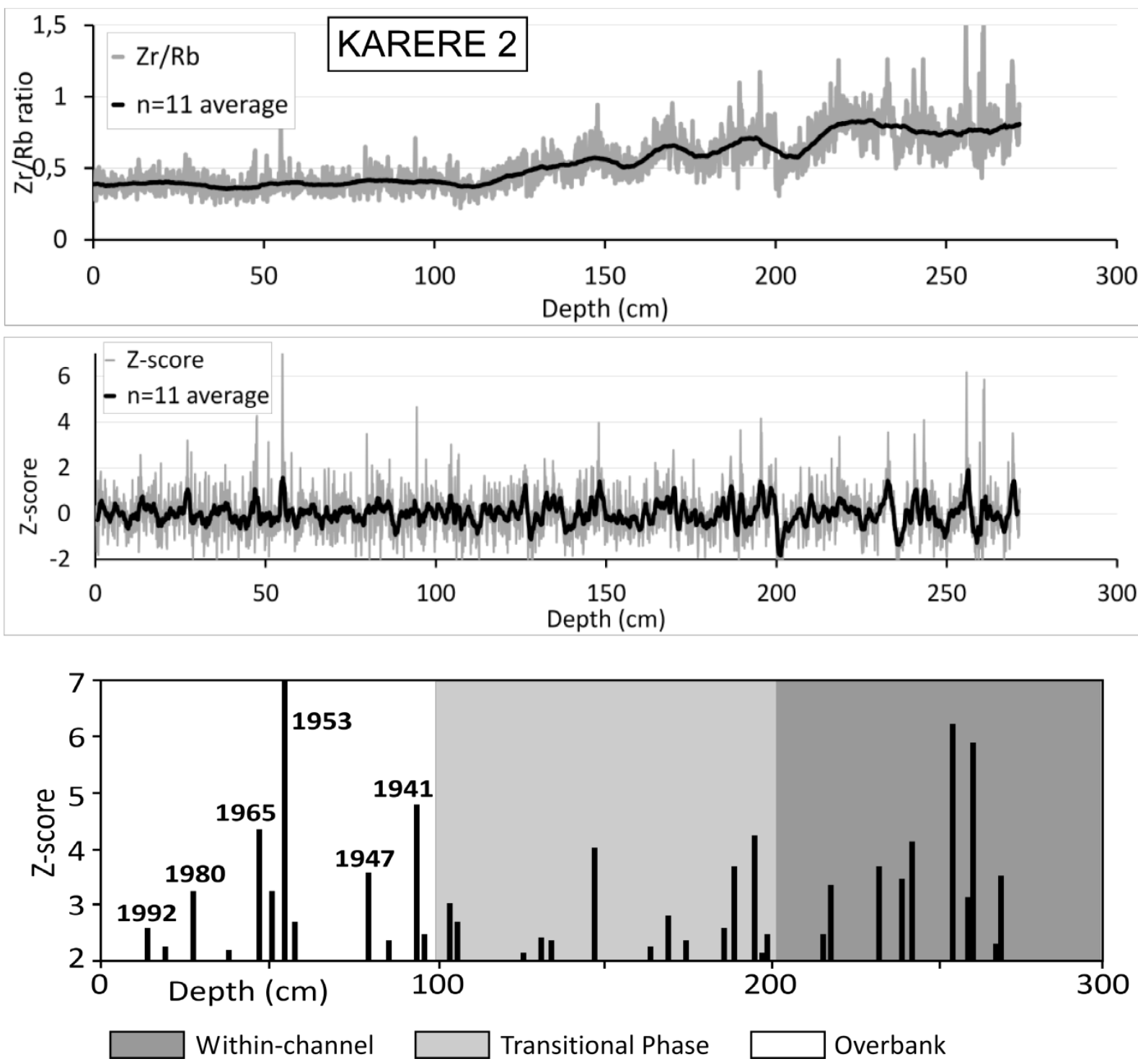

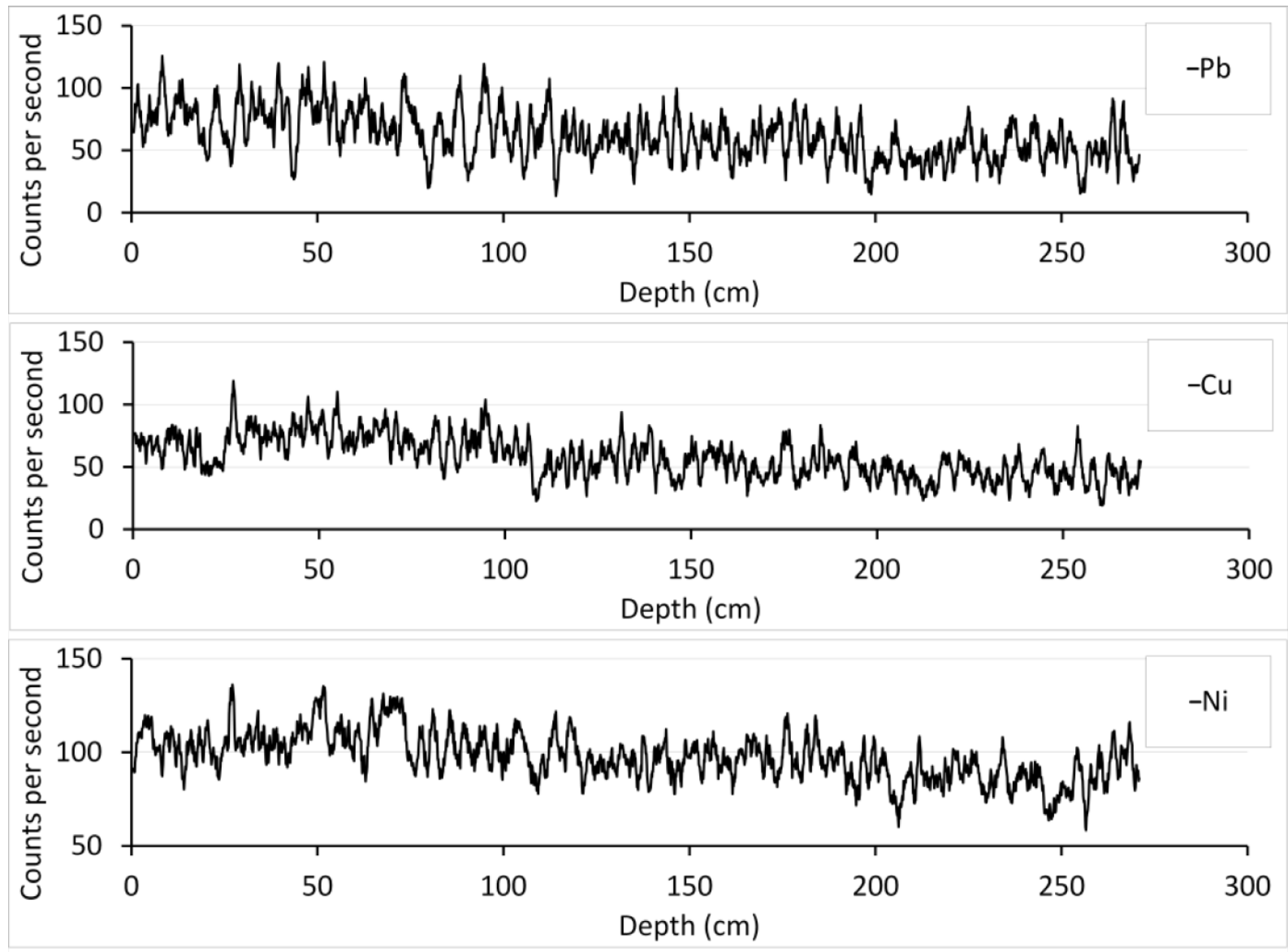

797

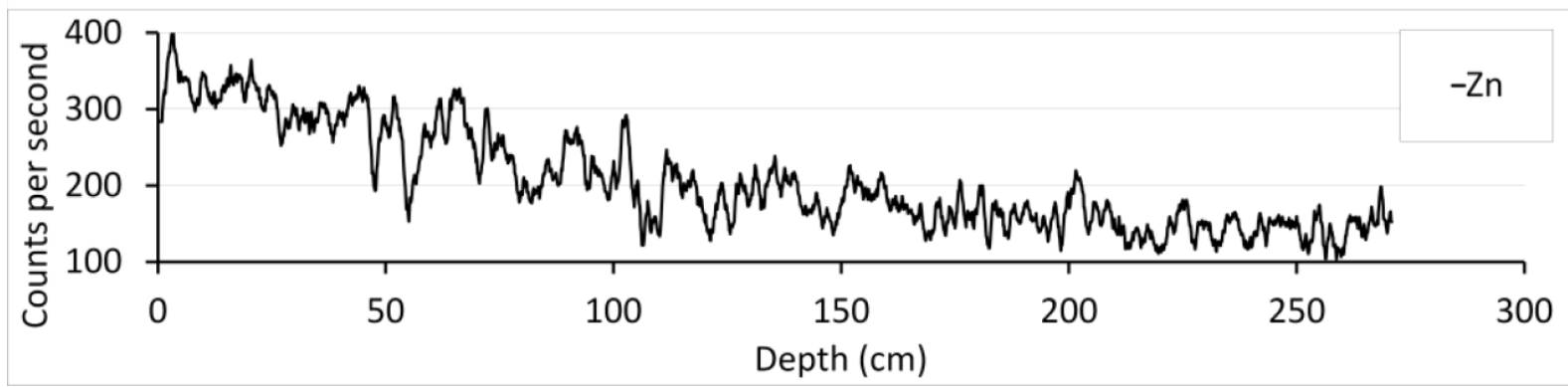

Figure A2 Karere 2 core: $\mathrm{Zr} / \mathrm{Rb}$ ratio, Z-score, inferred floods, heavy metal geochemistry $(\mathrm{Pb}, \mathrm{Cu}, \mathrm{Ni}$, $\mathrm{Zn})$. 

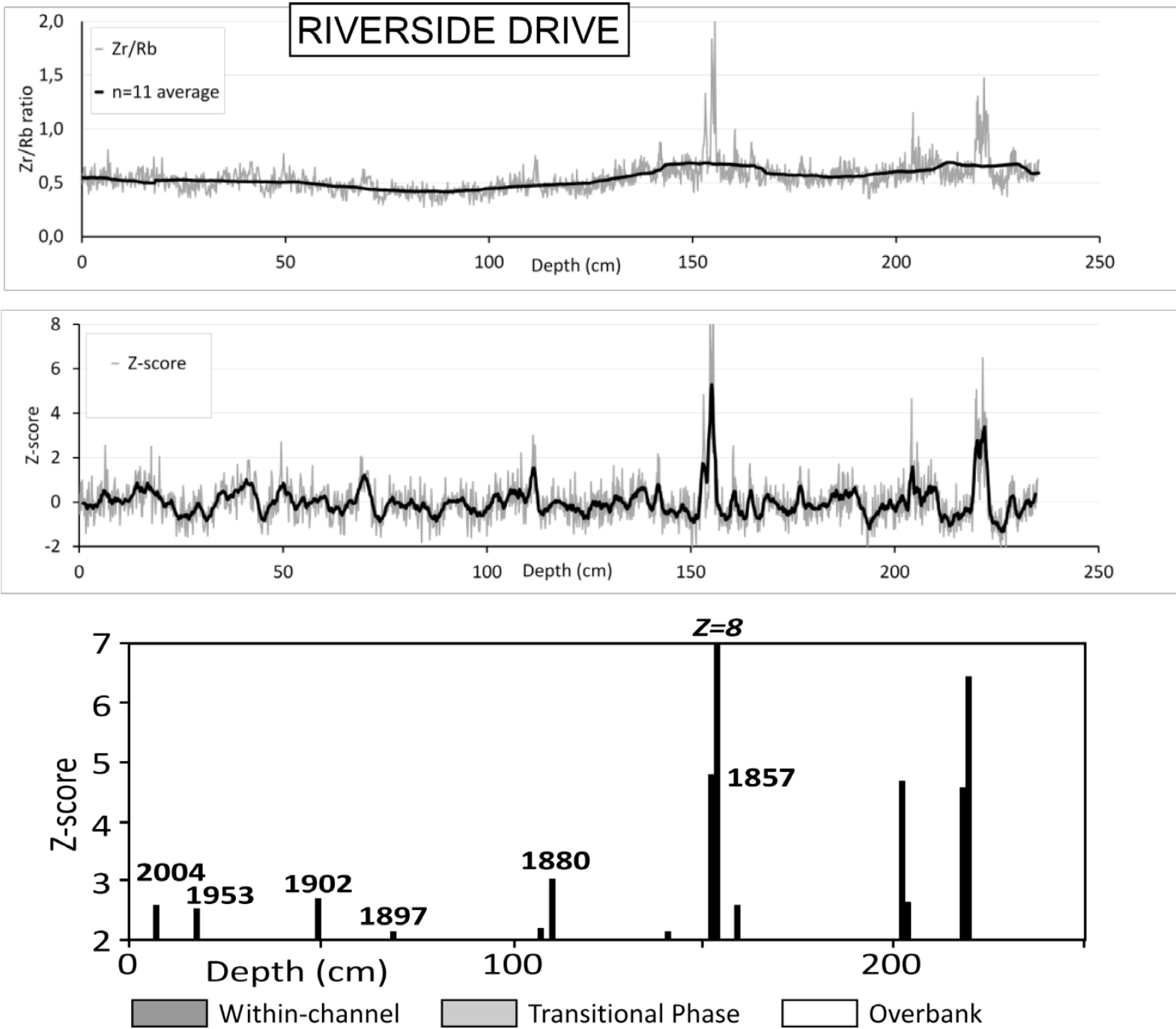

802 

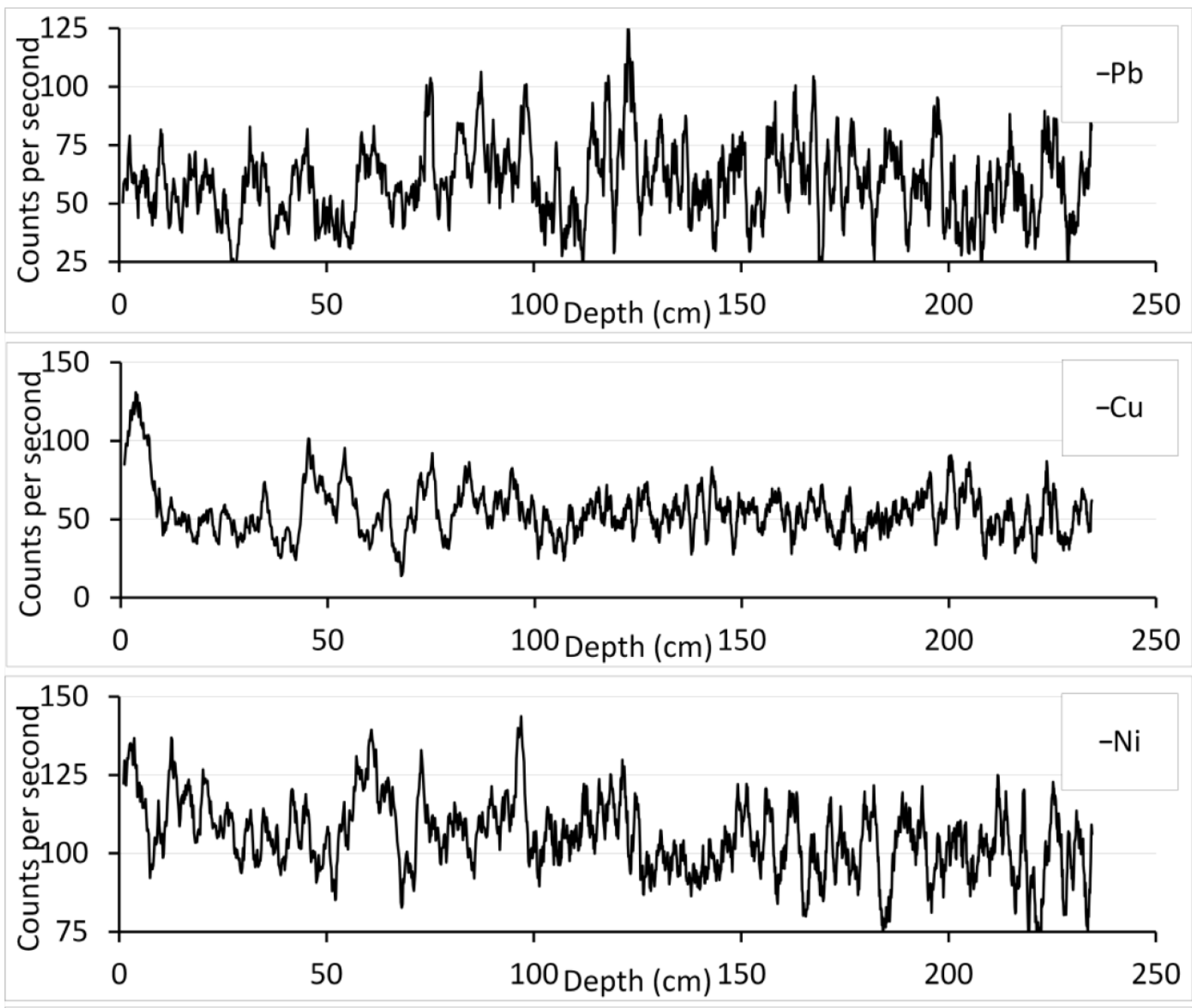

803

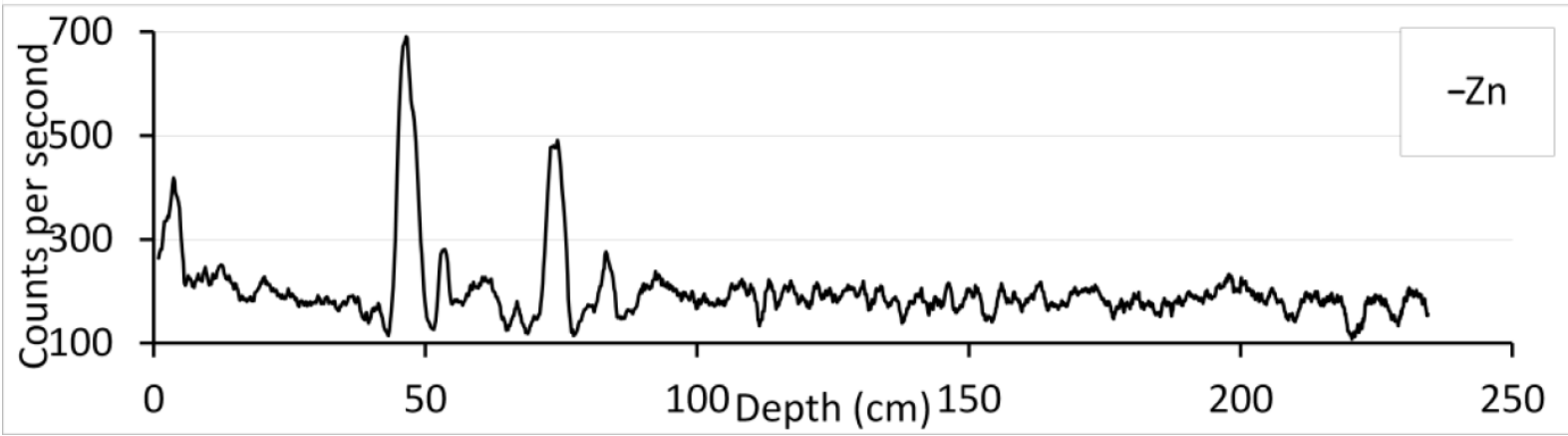

804 Figure $\mathbf{A} 3$ Riverside Drive core: $\mathrm{Zr} / \mathrm{Rb}$ ratio, Z-score, inferred floods, heavy metal geochemistry ( $\mathrm{Pb}$, $805 \mathrm{Cu}, \mathrm{Ni}, \mathrm{Zn})$ 

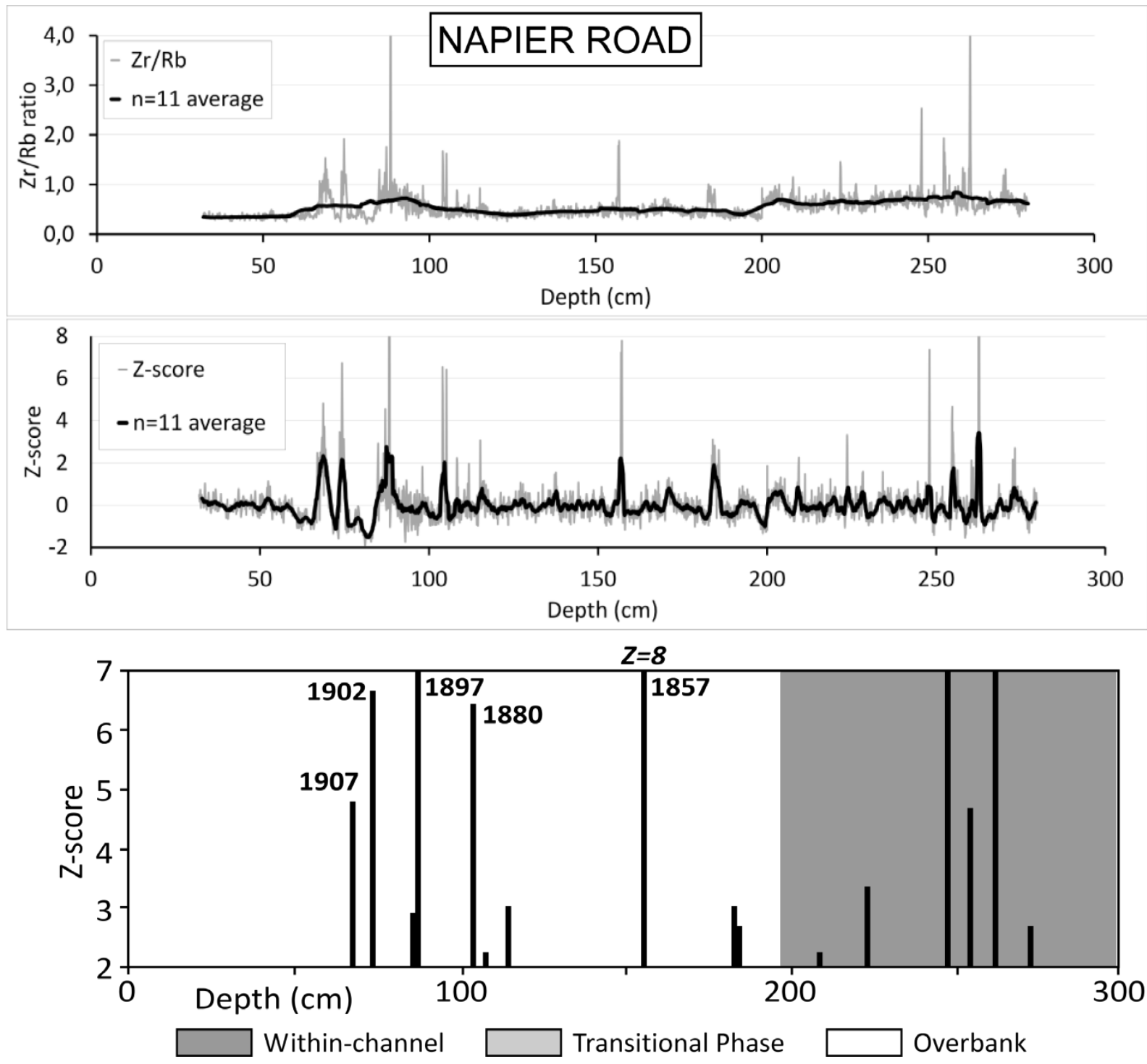

808 

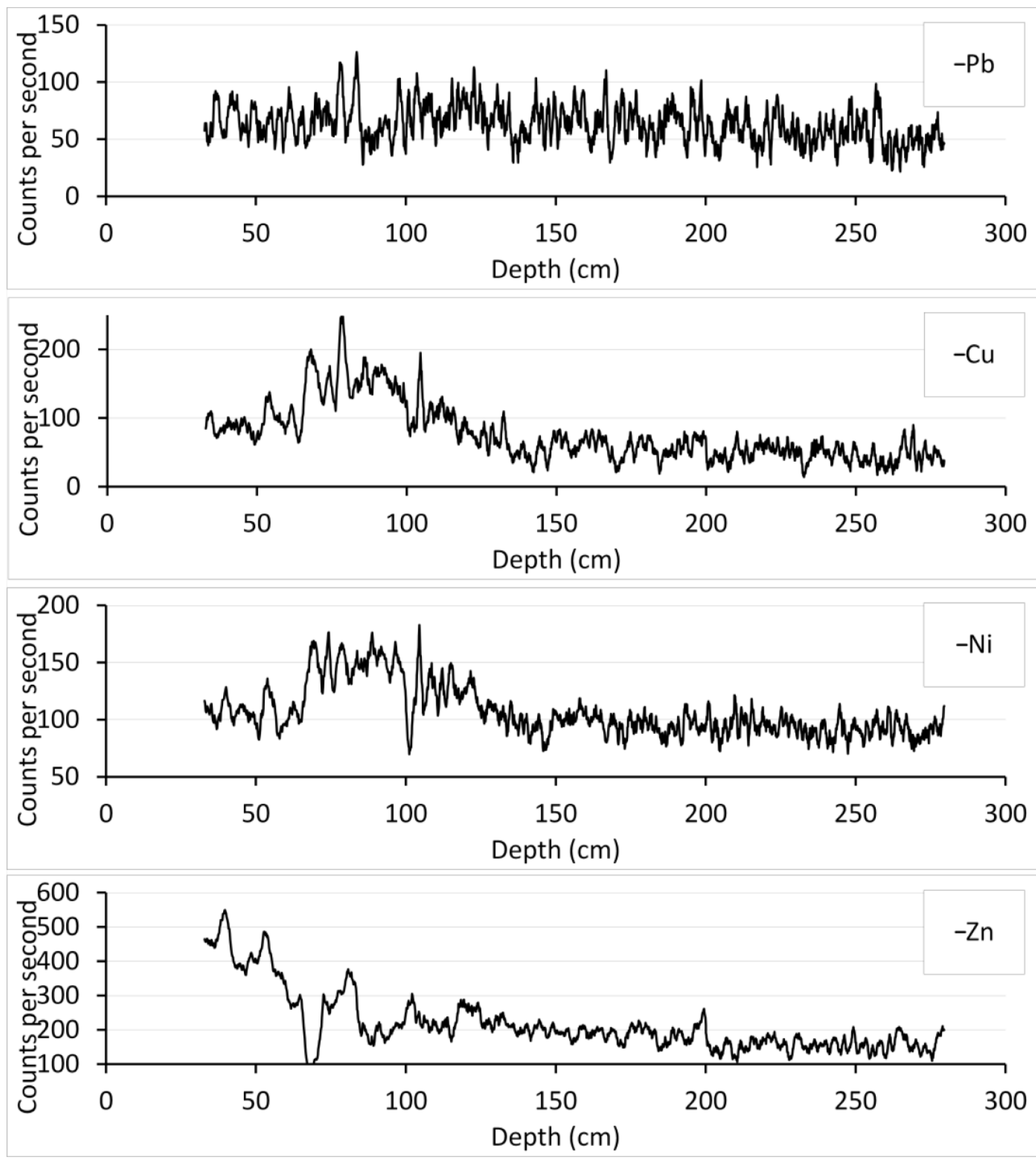

810 Figure $\mathrm{A4}$ Napier Road core: $\mathrm{Zr} / \mathrm{Rb}$ ratio, Z-score, inferred floods, heavy metal geochemistry $(\mathrm{Pb}, \mathrm{Cu}$, $811 \mathrm{Ni}, \mathrm{Zn})$ 

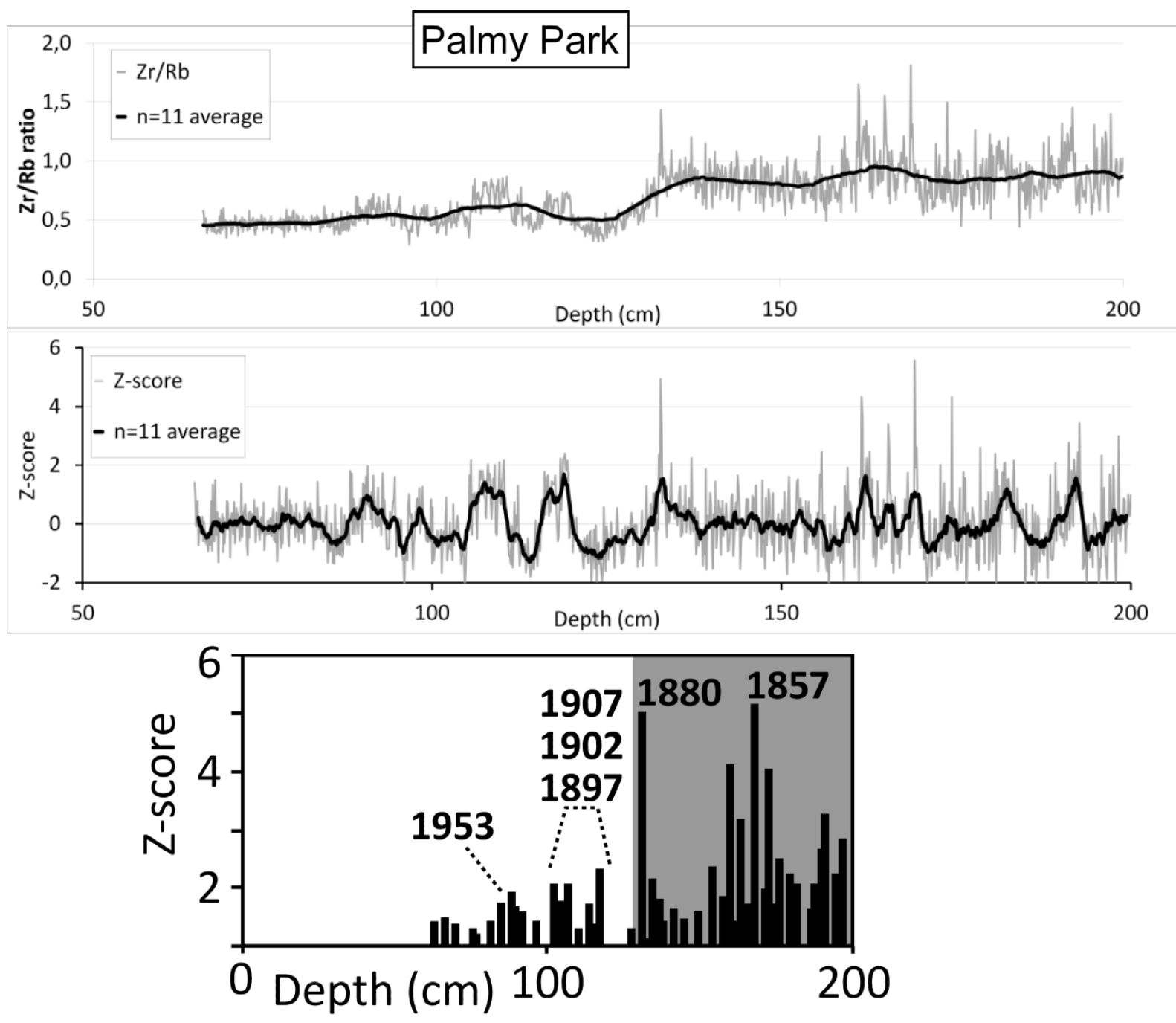

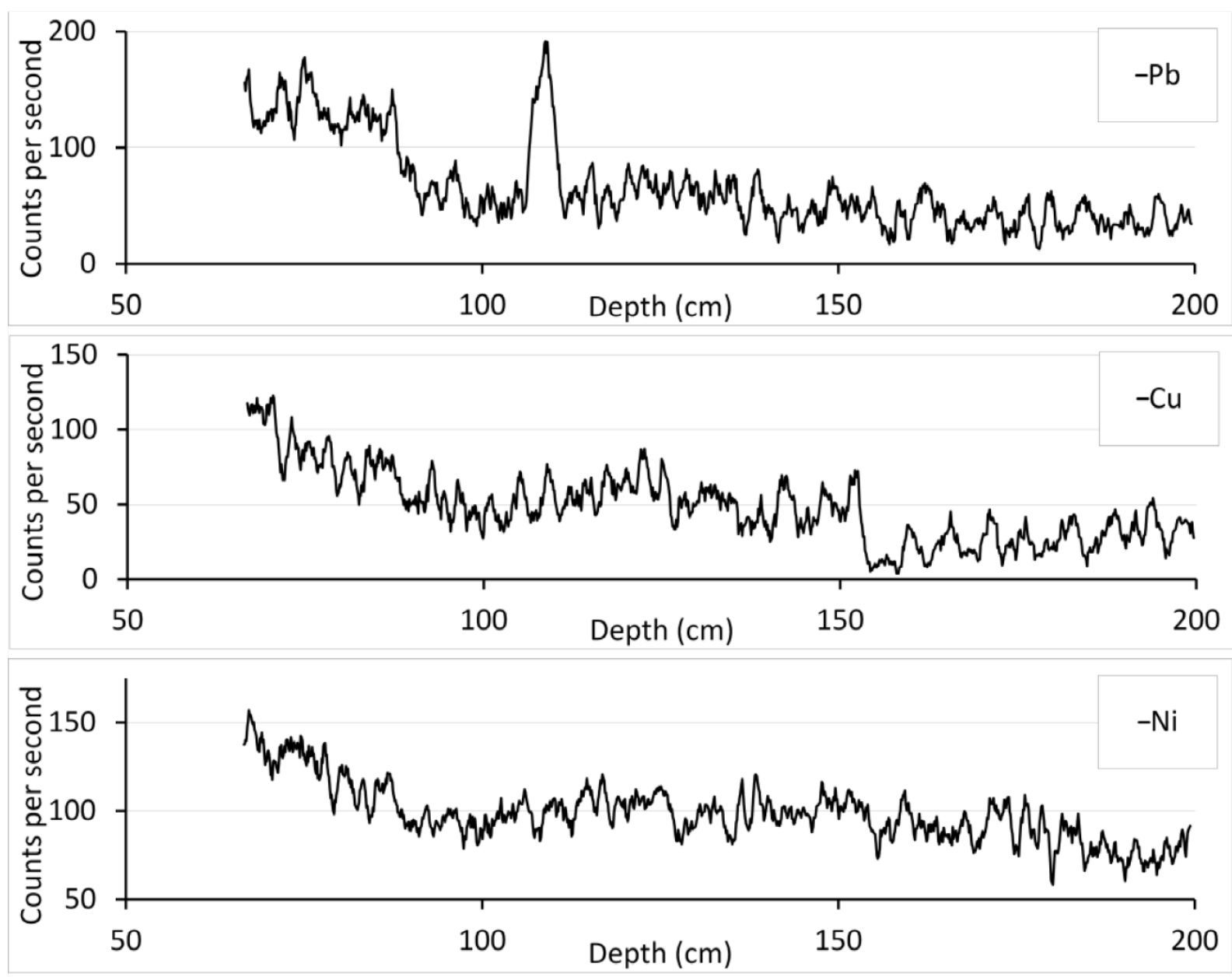

816 Figure A5 Palmy Park core: $\mathrm{Zr} / \mathrm{Rb}$ ratio, Z-score, inferred floods, heavy metal geochemistry (Pb, $\mathrm{Cu}$, $817 \mathrm{Ni}, \mathrm{Zn})$. 

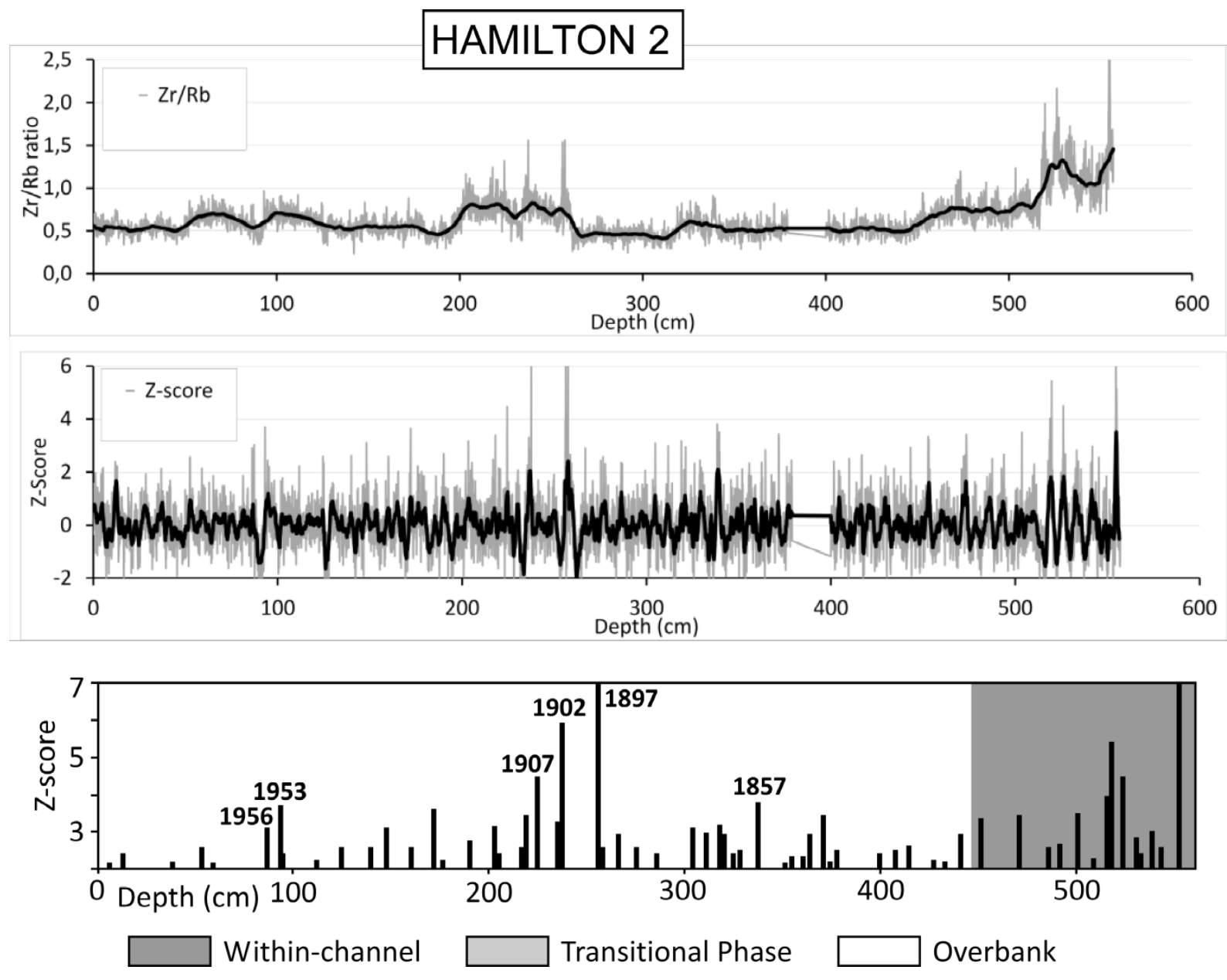

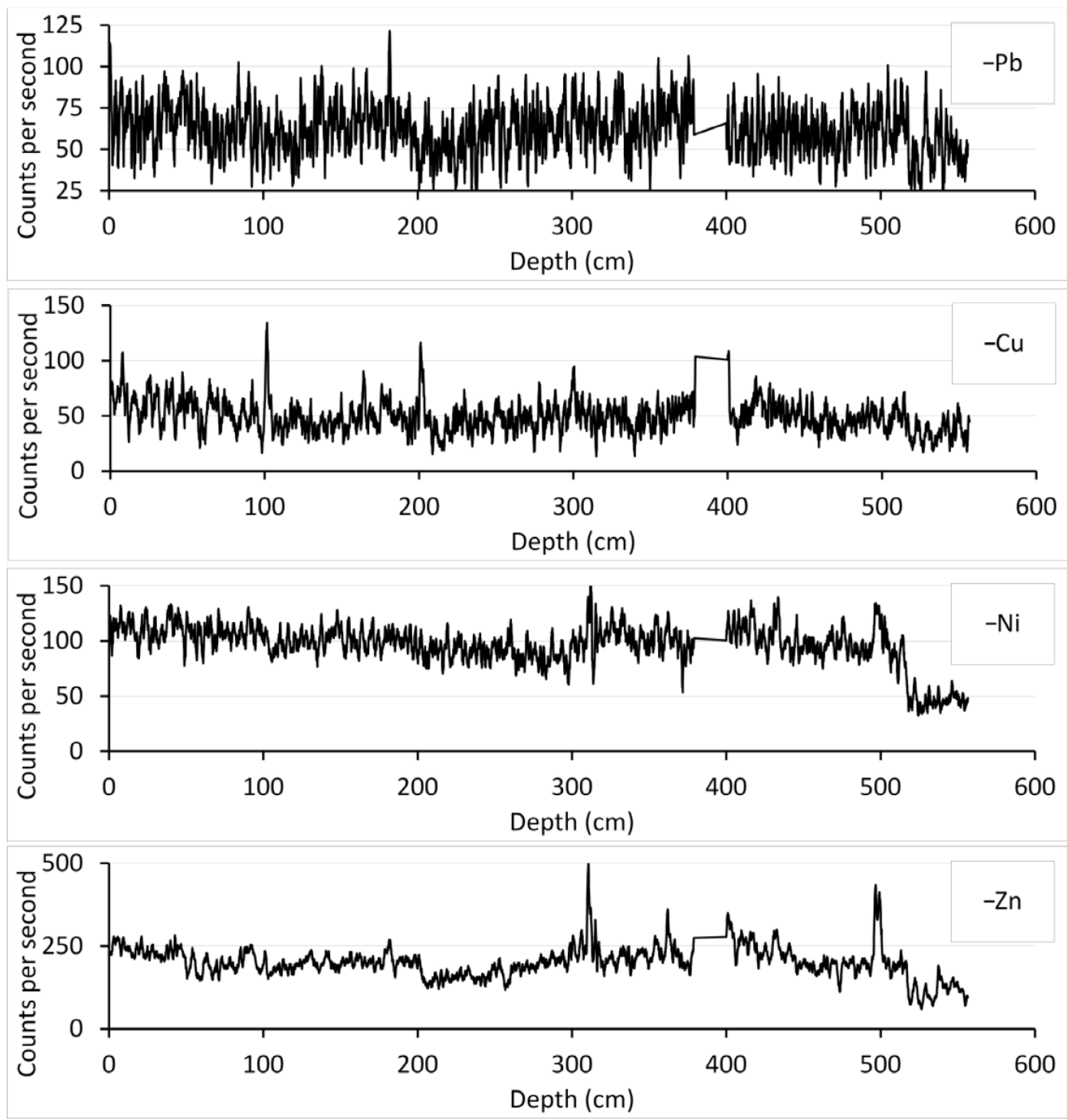

822 Figure A6 Hamilton 2 core: $\mathrm{Zr} / \mathrm{Rb}$ ratio, Z-score, inferred floods, heavy metal geochemistry ( $\mathrm{Pb}, \mathrm{Cu}$, $823 \mathrm{Ni}, \mathrm{Zn})$. 

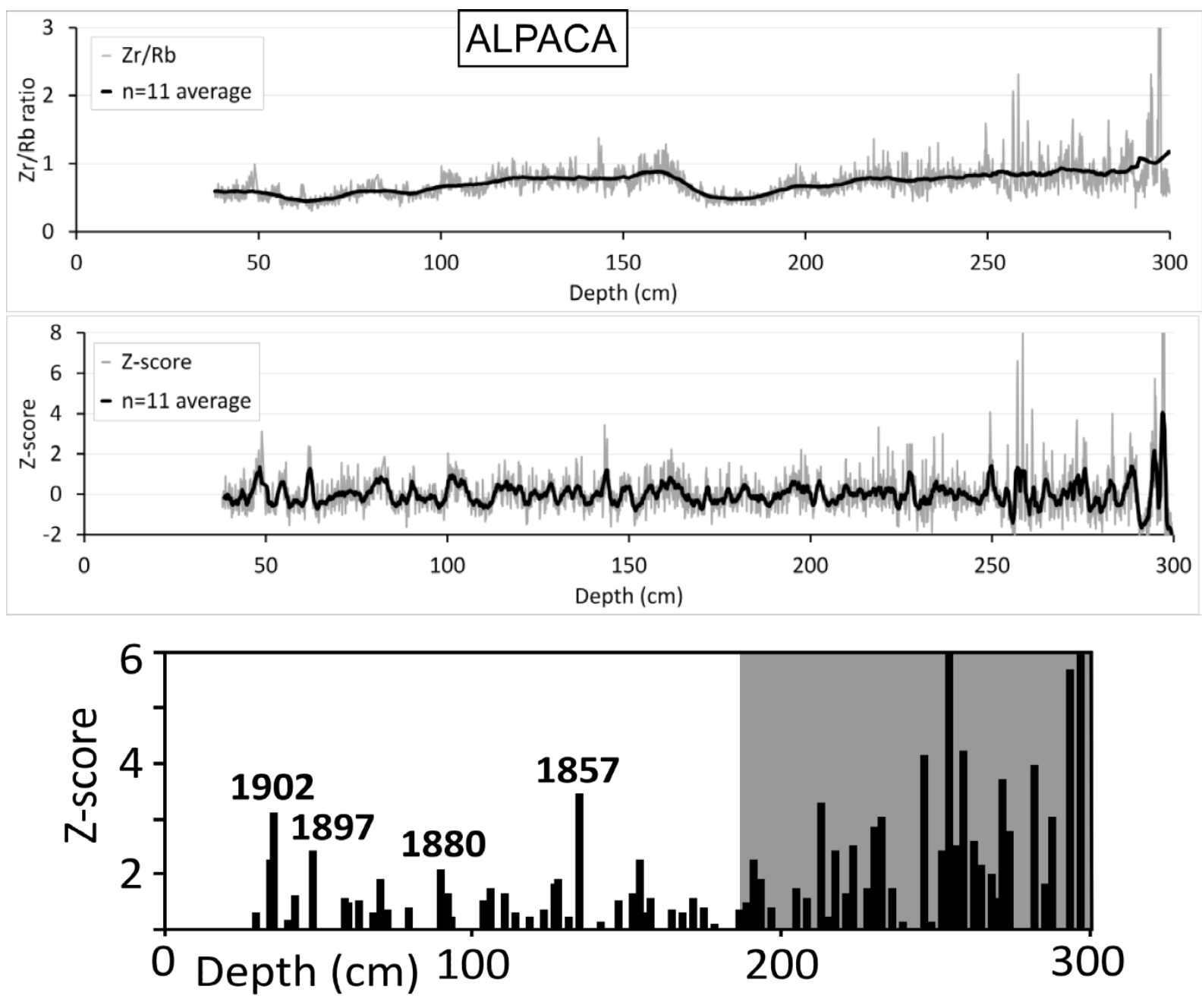

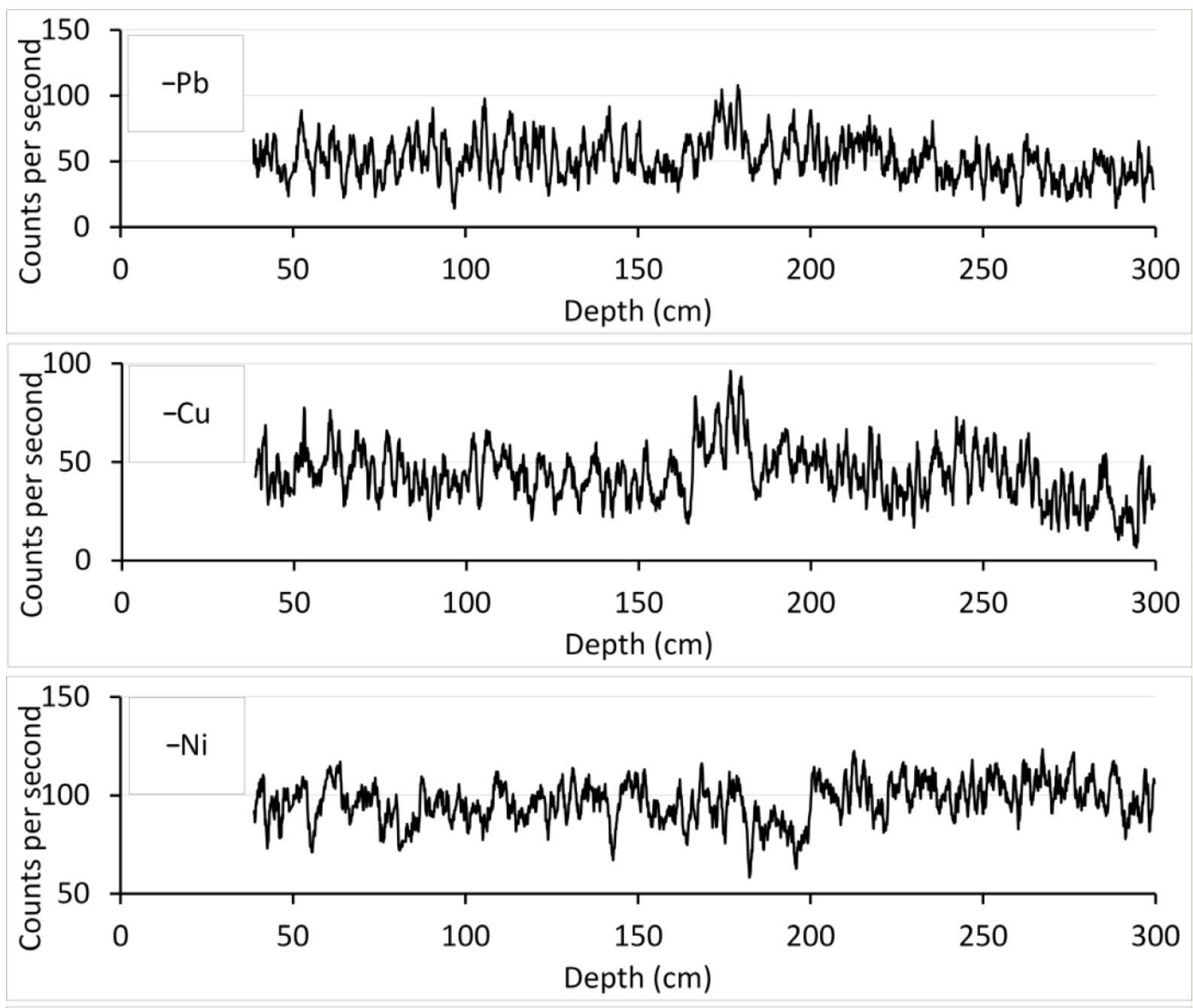

827

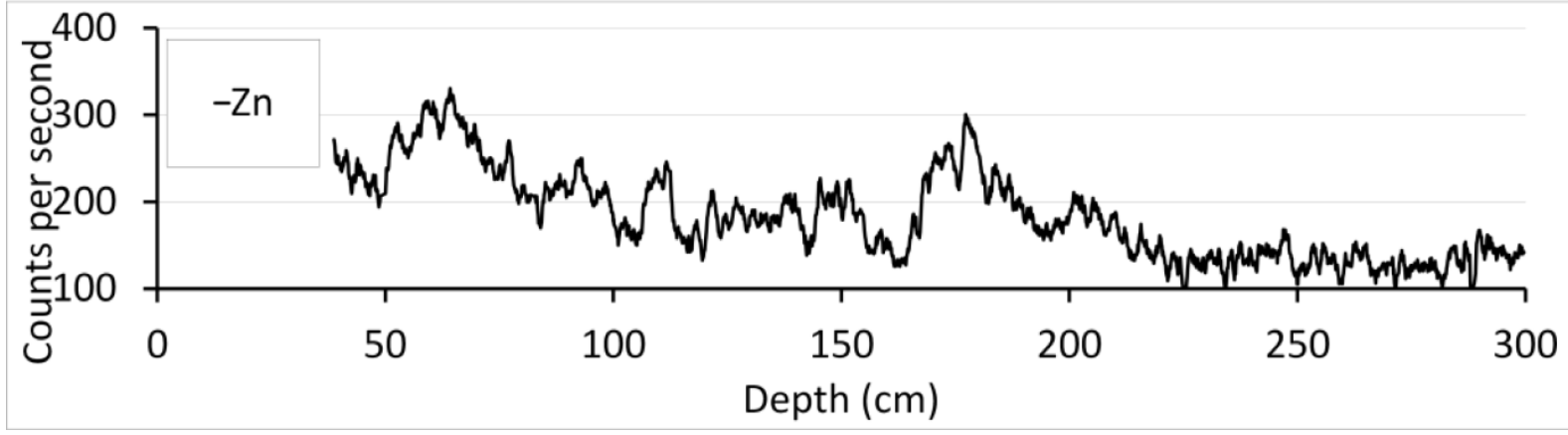

828 Figure $\mathbf{A 7}$ Alpaca core: $\mathrm{Zr} / \mathrm{Rb}$ ratio, $\mathrm{Z}$-score, inferred floods, heavy metal geochemistry ( $\mathrm{Pb}, \mathrm{Cu}, \mathrm{Ni}$, $829 \mathrm{Zn})$. 

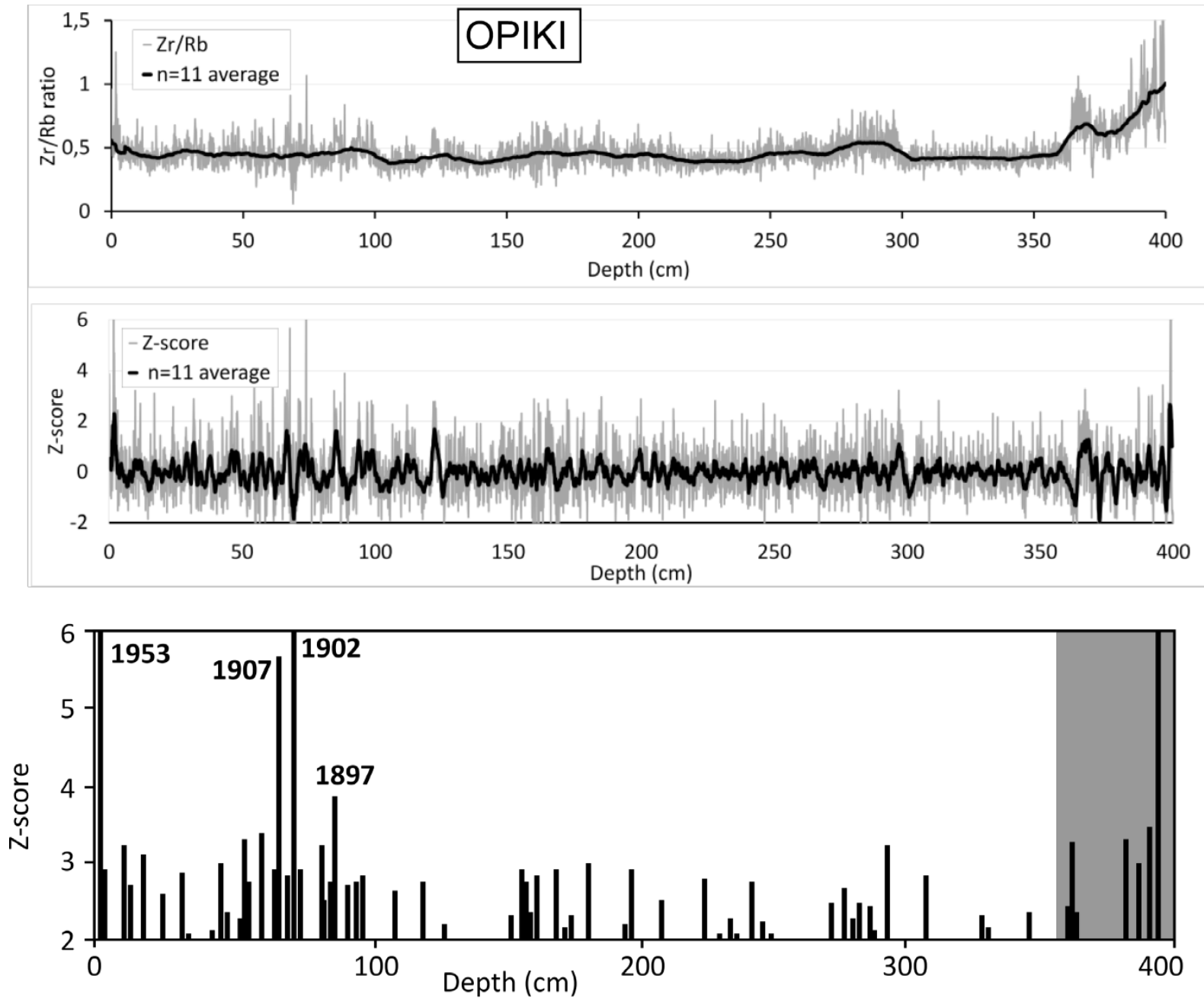

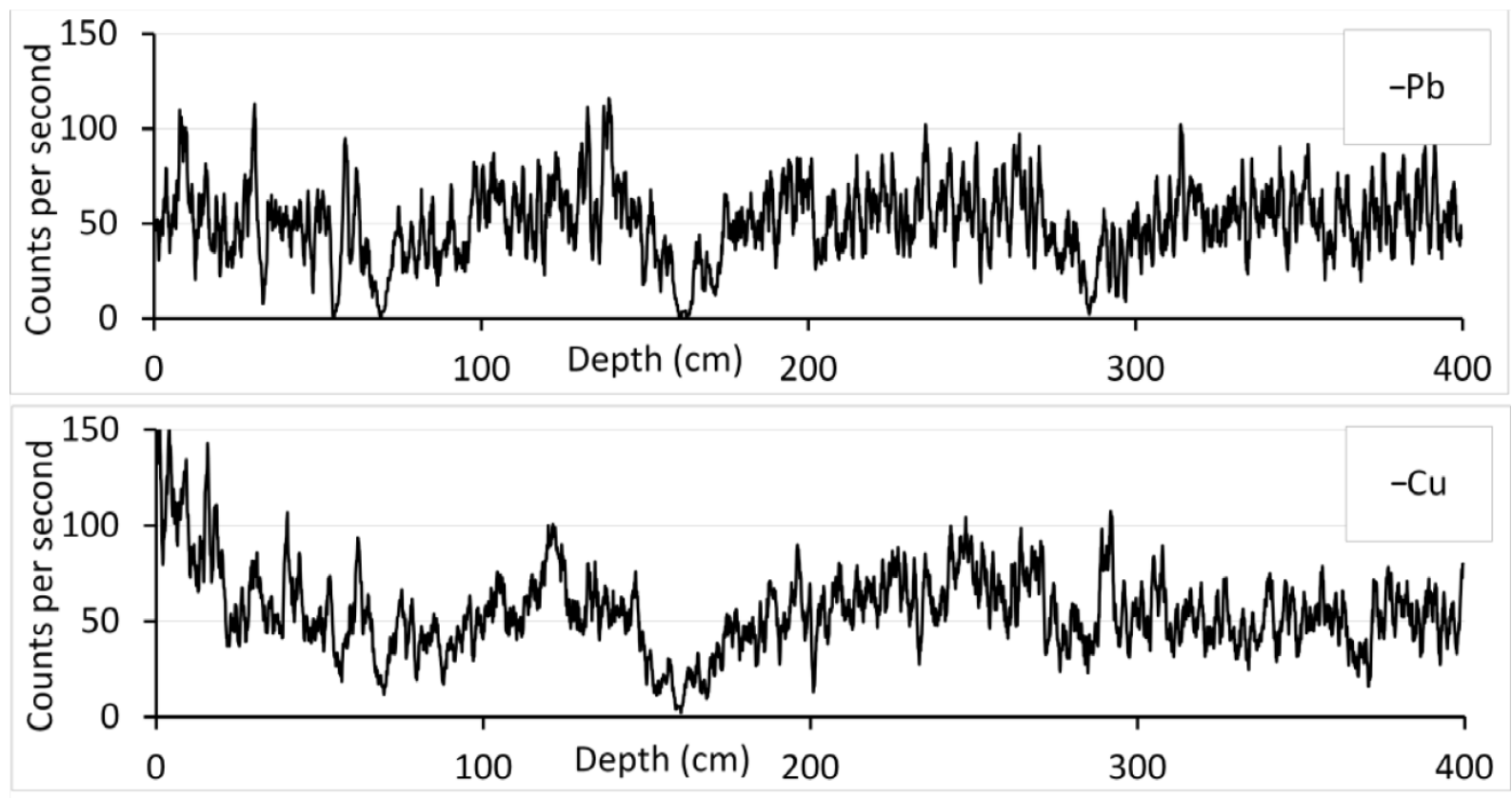

833
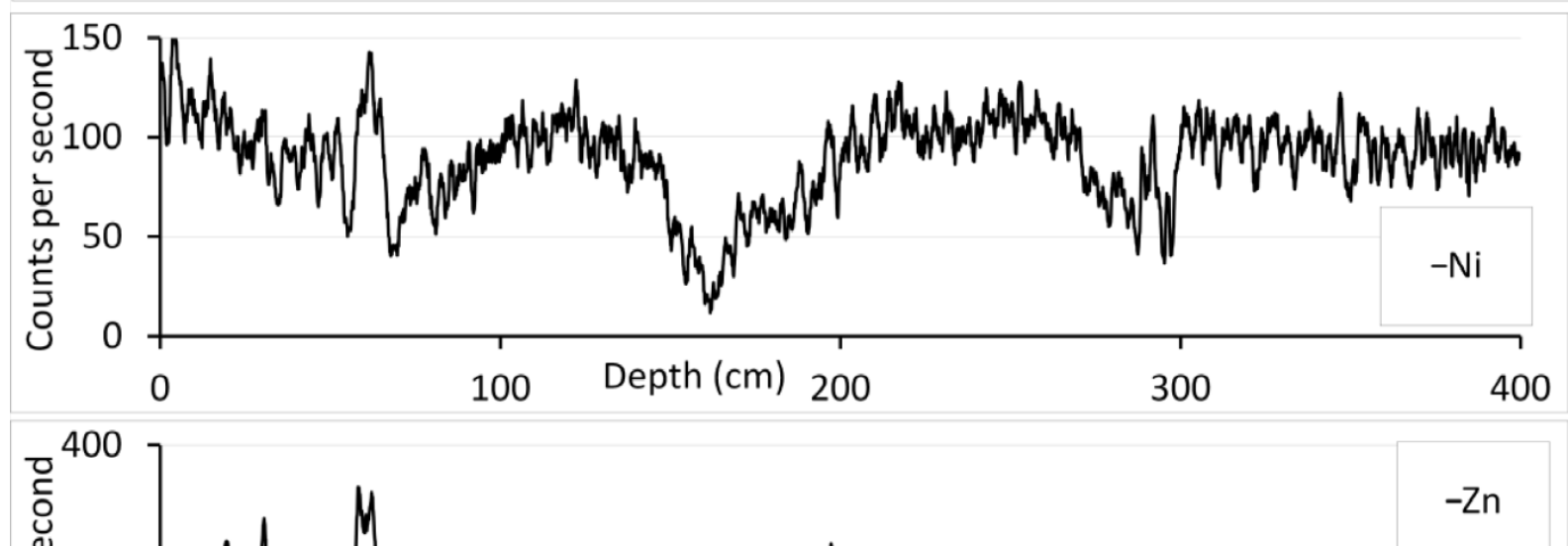

834 Figure A8 Opiki core: $\mathrm{Zr} / \mathrm{Rb}$ ratio, Z-score, inferred floods, heavy metal geochemistry ( $\mathrm{Pb}, \mathrm{Cu}, \mathrm{Ni}, \mathrm{Zn}$ ). 

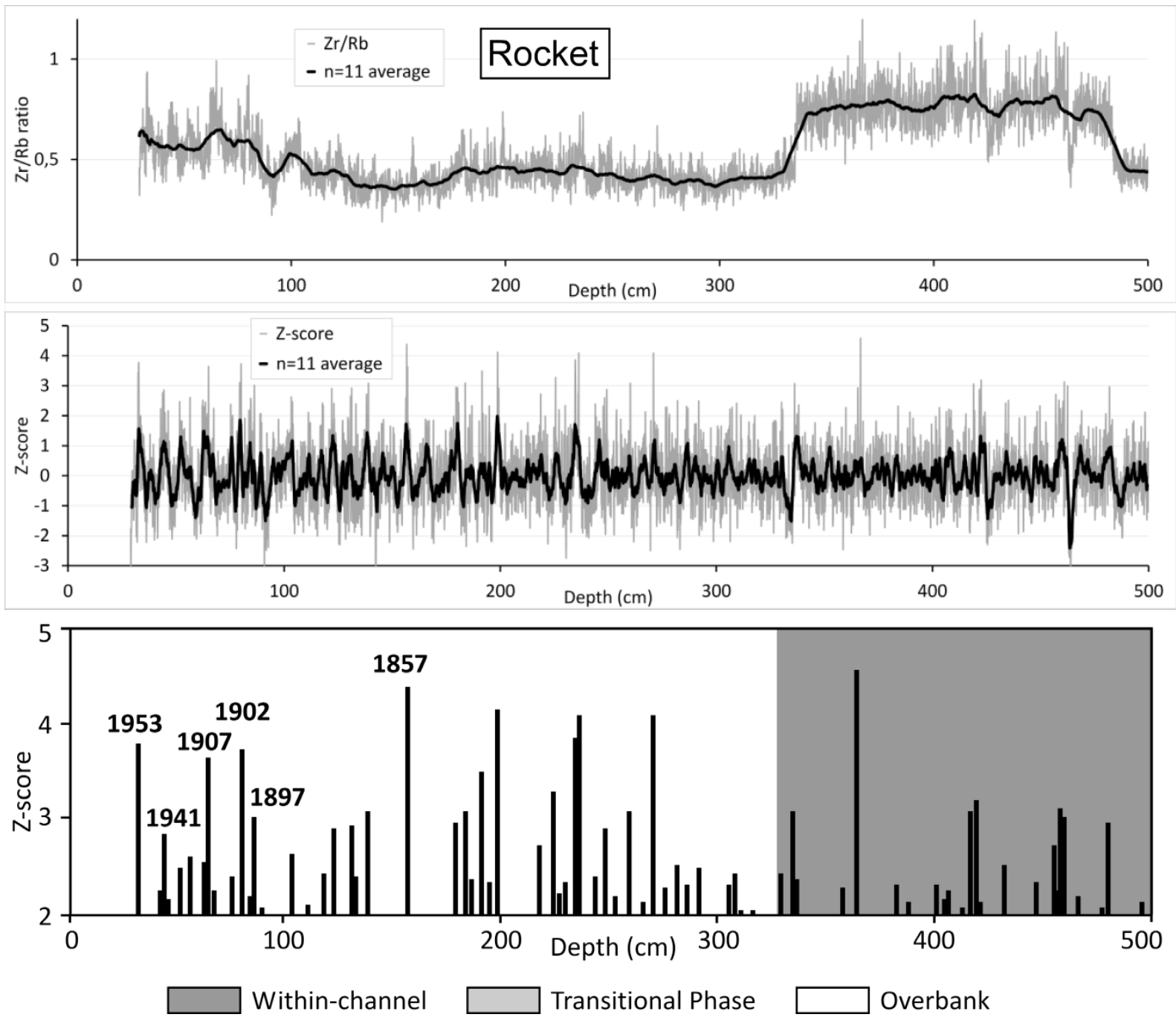


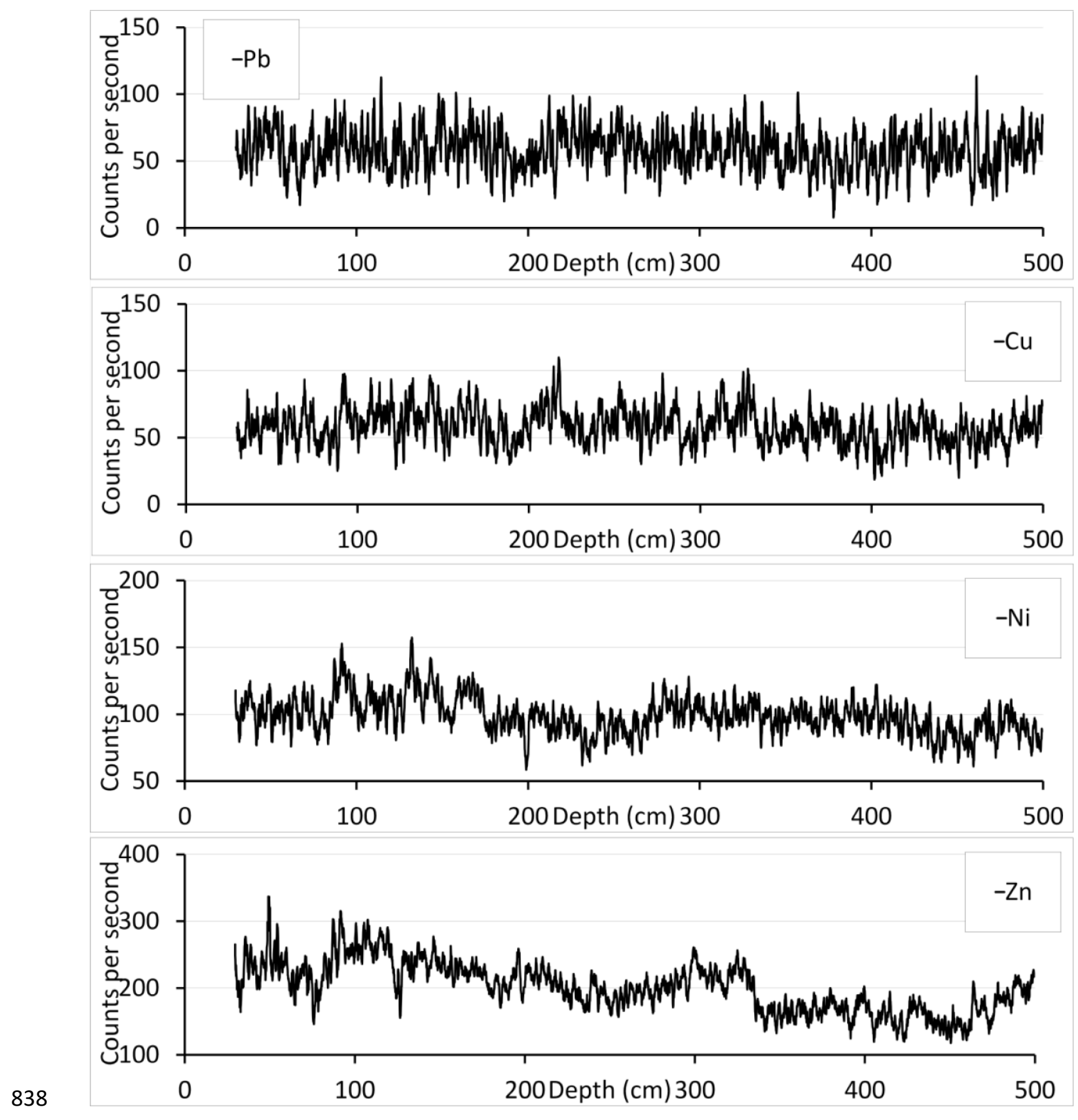

839 Figure $\mathrm{A9}$ Rocket core: $\mathrm{Zr} / \mathrm{Rb}$ ratio, $\mathrm{Z}$-score, inferred floods, heavy metal geochemistry $(\mathrm{Pb}, \mathrm{Cu}, \mathrm{Ni}$, $840 \mathrm{Zn})$. 